\title{
Sensitivity studies of dust ice nuclei effect on cirrus clouds with the Community Atmosphere Model CAM5
}

 \\ ${ }^{1}$ Atmospheric Science \& Global Change Division, Pacific Northwest National Laboratory, Richland, WA, USA \\ ${ }^{2}$ Institute of Atmospheric Physics, Chinese Academy of Sciences, Beijing, China \\ ${ }^{3}$ NASA Ames Research Center, Moffett Field, CA, USA \\ ${ }^{4}$ National Center for Atmospheric Research, Boulder, CO, USA \\ ${ }^{5}$ Global Modeling and Assimilation Office, NASA Goddard Space Flight Center, Greenbelt, MD, USA \\ ${ }^{6}$ I. M. Systems Group, Rockville, MD, USA \\ ${ }^{7}$ School of Earth and Atmospheric Sciences, Georgia Institute of Technology, Atlanta, GA, USA \\ ${ }^{8}$ School of Chemical and Biomolecular Engineering, Georgia Institute of Technology, Atlanta, GA, USA \\ ${ }^{9}$ SPEC Inc., Boulder, CO, USA \\ Correspondence to: X. Liu (xiaohong.liu@pnnl.gov)
}

Received: 22 March 2012 - Published in Atmos. Chem. Phys. Discuss.: 25 May 2012

Revised: 18 October 2012 - Accepted: 11 December 2012 - Published: 19 December 2012

\begin{abstract}
In this study the effect of dust aerosol on upper tropospheric cirrus clouds through heterogeneous ice nucleation is investigated in the Community Atmospheric Model version 5 (CAM5) with two ice nucleation parameterizations. Both parameterizations consider homogeneous and heterogeneous nucleation and the competition between the two mechanisms in cirrus clouds, but differ significantly in the number concentration of heterogeneous ice nuclei (IN) from dust. Heterogeneous nucleation on dust aerosol reduces the occurrence frequency of homogeneous nucleation and thus the ice crystal number concentration in the Northern Hemisphere (NH) cirrus clouds compared to simulations with pure homogeneous nucleation. Global and annual mean shortwave and longwave cloud forcing are reduced by up to $2.0 \pm 0.1 \mathrm{~W} \mathrm{~m}^{-2}$ ( $1 \sigma$ uncertainty) and $2.4 \pm 0.1 \mathrm{~W} \mathrm{~m}^{-2}$, respectively due to the presence of dust IN, with the net cloud forcing change of $-0.40 \pm 0.20 \mathrm{~W} \mathrm{~m}^{-2}$. Comparison of model simulations with in situ aircraft data obtained in $\mathrm{NH}$ mid-latitudes suggests that homogeneous ice nucleation may play an important role in the ice nucleation at these regions with temperatures of 205-230 K. However, simulations overestimate observed ice crystal number concentrations in the tropical tropopause regions with temperatures of 190 $205 \mathrm{~K}$, and overestimate the frequency of occurrence of high ice crystal number concentration $\left(>200 \mathrm{~L}^{-1}\right)$ and underes-
\end{abstract}

timate the frequency of low ice crystal number concentration $\left(<30 \mathrm{~L}^{-1}\right)$ at $\mathrm{NH}$ mid-latitudes. These results highlight the importance of quantifying the number concentrations and properties of heterogeneous IN (including dust aerosol) in the upper troposphere from the global perspective.

\section{Introduction}

Cirrus clouds composed of ice crystals cover roughly $30 \%$ of the globe (Wang et al., 1996; Wylie and Menzel, 1999), and have been shown to play an important role in modifying the global radiative balance through scattering shortwave radiation and absorbing and emitting longwave (LW) terrestrial radiation (Corti et al., 2005; Kay and Gettelman, 2009; Liou, 1986; Lohmann and Roeckner, 1995; Ramanathan and Collins, 1991). Cirrus clouds also modulate water vapor in the upper troposphere and lower stratosphere (Gettelman et al., 2002; Korolev and Isaac, 2006; Krämer et al., 2009).

Although cirrus clouds are an important player in the global climate system, there are still large uncertainties in the understanding of cirrus cloud processes (DeMott et al., 2003; Lohmann et al., 2008; Barahona and Nenes, 2011). Compared to droplet activation in warm clouds, ice nucleation in cold clouds is more complicated. There are 
multiple ice nucleation mechanisms identified depending on aerosol surface properties and environmental conditions. Cirrus clouds can be formed by the homogeneous freezing of cloud droplets and aerosol solution particles at low temperatures $\left(<-37^{\circ} \mathrm{C}\right)$ and high relative humidities over ice $\left(\mathrm{RH}_{\mathrm{i}}\right.$, 140-160 \%) (e.g., Koop et al., 2000). Cirrus clouds can also be formed by the heterogeneous nucleation of ice on aerosol particles (Pruppacher and Klett, 1997), called ice nuclei (IN).

Various insoluble or partly insoluble aerosol particles can act as IN in deposition, contact, immersion, and condensation "freezing" modes, such as mineral dust, metallic particles, and primary biological particles (Cziczo et al., 2004; DeMott et al., 2000; Szyrmer and Zawadzki, 1997). Although very scarce, heterogeneous IN could significantly impact the ice crystal number concentration compared to pure homogeneous freezing by initiating ice nucleation earlier, depleting available water vapor and ultimately hindering the occurrence of homogeneous freezing (Chen et al., 2000; DeMott et al., 1994; Kärcher and Lohmann, 2003; Liu and Penner, 2005; Barahona and Nenes, 2009a, b). The relative importance of heterogeneous IN depends on the concentration of IN as well as the cooling rate (DeMott et al., 1994; Kärcher and Lohmann, 2003). Till now the importance of heterogeneous IN on global upper tropospheric ice number concentrations remains unclear, partially due to the scarcity of IN measurements and instrument artifacts of in situ ice crystal number measurements (Heymsfield, 2007; McFarquhar et al., 2007). Recent measurements indicate that heterogeneous IN might play a more important role than was previously thought in the Tropical Tropopause Layer (TTL) with extreme low temperatures (less than $-70^{\circ} \mathrm{C}$ ) after correcting the measurement artifacts (Jensen et al., 2010) and after identifying new classes of particles and phase states that can act as IN (Abbatt et al., 2006; Murray et al., 2010).

There have been significant advancements in the development of ice nucleation parameterizations for large-scale models. Homogeneous freezing of aqueous solutions can be relatively well represented by theory (Koop et al., 2000). For heterogeneous nucleation, empirical fits of IN observations are often used (Cooper, 1986; Cotton et al., 1986; DeMott et al., 1998; Meyers et al., 1992). Heterogeneous ice nucleation rates can also be calculated using the classical nucleation theory (CNT) (Fletcher, 1962; Pruppacher and Klett, 1997; Khvorostyanov and Curry, 2000, 2004). CNT is a statistical method that parameterizes the rate of heterogeneous ice nucleation as a function of ambient conditions such as temperature and ice supersaturation, and properties of the IN such as size, contact angle of ice germ on the substrate and activation energy. Key parameters in CNT such as contact angle and activation energy can also be constrained using laboratory data for different types of aerosols (Chen et al., 2008), and possibly ambient observations (Curry and Khvorostyanov, 2012). Phillips et al. (2008) derived empirical formulations for parameterizing atmospheric IN as a function of surface area densities of aerosol species (mineral dust, black car- bon and hydrophobic organics) in addition to temperature and ice supersaturation, based on observations from several field campaigns obtained from the Colorado State University (CSU) Count Flow Diffusion Chamber (CFDC). Using a larger dataset obtained from the same CFDC, DeMott et al. (2010) derived an empirical formulation of the number concentration of IN in mixed-phase clouds as a function of temperature and number concentration of aerosol particles with sizes larger than $0.5 \mu \mathrm{m}$. Ice crystal number concentrations predicted from the CNT are much higher than those from the empirical method by Phillips et al. (2008), when both methods were tested in the same cloud parcel model framework for the same assumed aerosol distribution (Eidhammer et al., 2009).

Determining the ice crystal concentration in cirrus clouds require (in addition to a nucleation theory) knowledge of the supersaturation that develops in clouds; this is typically accomplished by considering a dynamical parcel framework (e.g., Pruppacher and Klett, 1997) and determining ice crystal number from the maximum supersaturation that develops. Kärcher and Lohmann (2002a, b) first derived a formulation for homogeneous freezing of sulfate solution droplets based on this approach. The parameterization was extended in Kärcher et al. (2006) to consider the competition of heterogeneous ice nucleation on mineral dust and black carbon with homogeneous nucleation. Liu and Penner (2005) presented a parameterization for ice number concentration for large-scale models based on parcel model numerical simulations, and considered the competition between homogeneous and heterogeneous nucleation at temperature less than $-35^{\circ} \mathrm{C}$. Heterogeneous nucleation was based on the CNT. The ice crystal concentration is related to updraft velocity, temperature, and aerosol concentration. Barahona and Nenes $(2009 a, b)$ provided a framework for ice nucleation parameterizations by solving analytically the parcel model equations. These parameterizations provide expressions for ice crystal number concentration, explicitly considering the effects of aerosol size and number, updraft velocity, and deposition coefficient, and the competition between homogeneous nucleation and heterogeneous nucleation. The IN nucleation "spectrum" (i.e., the number of IN as a function of parcel supersaturation) can have any forms and be derived from CNT or empirical data.

Using the Liu and Penner (2005) parameterization implemented in the Community Atmospheric Model version 3 (Liu et al., 2007), Liu et al. (2009) investigated the impacts of anthropogenic aerosol (black carbon and sulfate) on ice clouds and found that the effect of anthropogenic black carbon on cirrus clouds through ice nucleation depends critically on its ice nucleation efficiency assumed in the model and thus the relative importance of homogeneous and heterogeneous ice nucleation. Using the European Centre/Hamburg (ECHAM) general circulation model with the Kärcher et al. (2006) ice nucleation parameterization, Hendricks et al. (2011) studied the effects of heterogeneous IN (mineral dust and black 
carbon) on cirrus clouds, found that the annual zonal mean cloud ice number concentration is reduced by up to $20 \%$ in the tropics and $1-10 \%$ in the midlatitudes due to the heterogeneous IN. Significant reduction (up to $10 \%$ ) in the mean ice water content are modeled, which leads to the reduction of annual and zonal mean water vapor mixing ratio of up to $5 \%$ at cirrus levels.

In this study, the ice nucleation parameterization of Barahona and Nenes (2009b, hereafter as BN09) was implemented in the Community Atmosphere Model version 5 (CAM5), which is the atmospheric component of the Community Earth System Model version 1 (CESM1). Together with the existing Liu and Penner (2005, hereafter as LP05) ice nucleation parameterization in CAM5, we investigate the sensitivity of cirrus clouds to different formulations of heterogeneous ice nucleation (through its competition with homogeneous freezing). Modeled ice crystal number concentration and $\mathrm{RH}_{\mathrm{i}}$ are compared with available observational data to understand the ice nucleation mechanisms in the upper troposphere. Sensitivity tests for pure homogeneous and pure heterogeneous nucleation were performed to examine the importance of heterogeneous IN from dust aerosol. The paper is organized as follows. Model description is presented in Sect. 2. Section 3 compares modeled ice crystal number concentrations from different parameterizations. Section 4 compares model results with observational data. Section 5 presents atmospheric impacts of dust IN and conclusions are in Sect. 6.

\section{Model description}

\subsection{CAM5}

This study uses CAM5, the latest released version of CAM (Neale et al., 2010). Compared to CAM version 3 (Collins et al., 2006a, b), several important physics components have been updated. CAM5 includes a two-moment stratiform cloud microphysics scheme (Morrison and Gettelman, 2008, hereafter as MG08; Gettelman et al., 2008). The model radiation scheme has been updated to the Rapid Radiative Transfer Model for GCM described by Iacono et al. (2008). The deep convective scheme has been modified following Neale et al. (2008). The shallow convective scheme follows that of Park and Bretherton (2009). The moist boundary layer scheme is based on Bretherton and Park (2009). The cloud condensation parameterization uses a new liquid cloud macrophysics closure described by Park et al. (2012). The aerosol treatment in the model uses the modal aerosol module (MAM) (Liu et al., 2012). MAM treats the internal mixing within a mode and external mixing between modes of major aerosol species (sulfate, black carbon, primary organic carbon, secondary organic carbon, mineral dust and sea salt), and predicts mass mixing ratio of different aerosol species in each mode and number mixing ratio of each mode. Specifi- cally, mineral dust important for this study is emitted in the accumulation mode with the size (diameter) range of 0.1$1 \mu \mathrm{m}$ and coarse mode with the size (diameter) range of $1-$ $10 \mu \mathrm{m}$ following the emission scheme of Zender et al. (2003). Once in the atmosphere, mineral dust is transported horizontally and vertically, and is removed by the dry and wet deposition. On the annual average, $\sim 62 \%$ of the global emitted dust mass is removed by the dry deposition (mainly by the gravitational settling) predicted by MAM, while wet deposition removes $\sim 85 \%$ of dust mass in the accumulation mode (Liu et al., 2012).

\subsection{Ice cloud scheme in CAM5}

Gettelman et al. (2010) modified cloud microphysics and macrophysics closure related to ice phase for CAM5 as compared to the CAM version 3.5 used in MG08. This includes: (1) condensation closure was modified to perform saturation adjustment only for liquid water. This allows the supersaturation over ice in ice clouds. Water vapor deposition onto ice crystals in mixed-phase and ice clouds is treated with process rate calculations. Sublimation occurs when water vapor is sub-saturated over ice; (2) the Bergeron-Findeisen process is treated for mixed-phase clouds to deplete cloud liquid given the assumption that water vapor is saturated with respect to water in mixed-phase clouds; (3) the diagnostic fractional cloudiness scheme for ice clouds is still based on Slingo (1987), but calculated using the total water, not just water vapor; and (4) ice nucleation in MG08 is changed as discussed in Sect. 2.3.

\subsection{Ice nucleation parameterizations in the standard CAM5}

Along with vapor deposition, ice nucleation provides a source for cloud ice in MG08. Sink terms include aggregation, autoconversion, accretion, melting and sedimentation. Aggregation reduces the ice particle number only and conserves the ice water content, while the other sinks mentioned above affect both quantities. The empirical temperaturebased IN parameterization from Cooper (1986) in MG08 was replaced in CAM5 with an explicit ice nucleation scheme with links to the aerosol concentration and type (Gettelman et al., 2010). Ice nucleation is based on Liu et al. (2007), which includes homogeneous nucleation on sulfate, heterogeneous immersion freezing on mineral dust and competition between the two mechanisms at temperatures below $-37{ }^{\circ} \mathrm{C}$ (Liu and Penner, 2005). Although LP05 includes the immersion nucleation on soot it is not considered in this work as it is still highly uncertain (Kärcher et al., 2007). In the LP05 parameterization, nucleated ice crystal number concentration is computed based on temperature, relative humidity, sulfate and dust number concentration, and sub-grid updraft velocity. The sub-grid variability of updraft velocity needed for driving the parameterization is derived from 
the square root of turbulent kinetic energy (TKE) (Bretherton and Park, 2009) with an assumed maximum threshold value of $0.2 \mathrm{~m} \mathrm{~s}^{-1}$ (Gettelman et al., 2010). The limiting IN number concentration above which homogeneous nucleation is prevented is derived from parcel model simulations as a function of temperature and sub-grid updraft velocity, and used in the parameterization of the competition between homogeneous and heterogeneous ice nucleation. We find that the subgrid variability of updraft velocity tends to be near $0.2 \mathrm{~m} \mathrm{~s}^{-1}$ (the upper limit) much of the time in CAM5. Our analysis of vertical velocity measurements in the Interhemispheric Differences in Cirrus Properties From Anthropogenic Emissions (INCA) and Small Particles in Cirrus (SPartICus) campaigns indicates higher mean updraft velocities than the upper threshold limit of $0.2 \mathrm{~m} \mathrm{~s}^{-1}$ (Zhang et al., 2012). This upper threshold limit is also lower than that seen in the observations in the tropical anvil cirrus of $0.30-0.5 \mathrm{~m} \mathrm{~s}^{-1}$ (Jensen et al., 2009). However, the model may predict too high sub-grid updraft velocity at high altitudes (e.g., near the tropopause) (Hoyle et al., 2005). Too high updraft velocity may produce anomalously high ice supersaturations, which may induce a homogeneous ice nucleation bias. The effects of sub-grid updraft velocity on the ice nucleation in cirrus clouds will be investigated in our future study.

In mixed-phase clouds with temperatures between 0 and $-35^{\circ} \mathrm{C}$, contact freezing of cloud droplets through Brownian coagulation with insoluble IN (assumed to be mineral dust) (Young, 1974), deposition/condensation nucleation (Meyers et al., 1992), and immersion freezing of cloud droplets (Bigg, 1953) are included. Ice multiplication through HalletMossop secondary ice production due to accretion of drops by snow is included following Cotton et al. (1986). More detailed description can be found in Gettelman et al. (2010).

We note that there are a few changes between this study and Gettelman et al. (2010) in CAM5 for the LP05 parameterization: (1) We use all Aitken mode sulfate aerosol for homogeneous nucleation while Gettelman et al. (2010) used a portion of the Aitken mode sulfate with diameter greater than $0.1 \mu \mathrm{m}$; (2) Accumulation mode dust $(0.1$ to $1.0 \mu \mathrm{m}$ diameter) in addition to coarse mode dust $(1.0-10.0 \mu \mathrm{m}$ diameter $)$ is used in the ice nucleation; and (3) We extend the LP05 parameterization for ice nucleation in pure ice clouds with temperatures between 0 and $-37^{\circ} \mathrm{C}$ where only heterogeneous nucleation occurs. This change is to be consistent with BN09 parameterization which includes ice nucleation for pure ice clouds at temperatures less than $-37^{\circ} \mathrm{C}$ as well as temperatures between 0 and $-37^{\circ} \mathrm{C}$. We note that the third modification has a small impact on model results (not shown).

\subsection{BN09 Parameterizations in CAM5}

For this study, we implemented the BN09 framework in CAM5. This framework explicitly considers the competition between homogeneous and heterogeneous freezing, and has the flexibility of using different IN "nucleation spectra" ei-
Table 1. CAM5 cases in this study.

\begin{tabular}{ll}
\hline Case Name & Description \\
\hline LP & LP05, combined nucleation \\
LPhom & LP05, pure homogeneous nucleation \\
LPhet & LP05, pure heterogeneous nucleation \\
\hline BN & BN09, combined nucleation \\
BNhom & BN09, pure homogeneous nucleation \\
BNhet & BN09, pure heterogeneous nucleation \\
\hline
\end{tabular}

ther from empirical correlations derived from observation data or from CNT. The "nucleation spectrum" describes the number of ice crystals nucleated from IN as a function of ice supersaturation. In the version of the BN09 code used in this study, there are four options for "nucleation spectrum". The first one (MY92) is derived from in-situ measurements of IN concentrations for temperature between $250 \mathrm{~K}$ and $266 \mathrm{~K}$ and ice supersaturation between $2 \%$ and $25 \%$ following Meyers et al. (1992). The second one (PDG07) is also based on in-situ measurement described by Phillips et al. (2007). The third one (PDA08), presented by Phillips et al. (2008), is a more comprehensive formulation that takes the surface area contribution from different types of aerosol (i.e., dust and soot) with sizes larger than $0.1 \mu \mathrm{m}$ diameter and freezing modes (i.e., deposition and immersion) into account. The last one is derived from a semi-empirical form of CNT. The PDA08 is used in this study as it uses fewer tuning parameters. Barahona et al. (2010) carried out sensitivity studies using a global chemical transport model with four different nucleation spectra and found that when the competition between homogeneous and heterogeneous freezing is considered, global mean ice crystal number concentration vary by up to a factor of twenty depending on the nucleation spectrum used.

Under the BN09 framework, the number of ice crystals nucleated is a function of aerosol number concentration, temperature, updraft velocity, and accommodation coefficient for water vapor deposition on ice crystals. Ice crystal number is derived from solving equations for temperature, ice supersaturation, and ice water content for an ascending air parcel with initial condition that is saturated with respect to ice. For consistency, the same sub-grid updraft velocity is used to drive both BN09 and LP05. BN09 is applied only for pure ice clouds (i.e., cirrus clouds with temperatures less than $-37^{\circ} \mathrm{C}$ as well as pure ice clouds with temperatures between 0 and $-37^{\circ} \mathrm{C}$ when only heterogeneous nucleation takes place). In mixed-phase clouds, we use the same heterogeneous ice nucleation parameterizations as in Gettelman et al. (2010), as documented in Sect. 2.3. 


\section{Modeled ice crystal number concentrations}

We run CAM5 with prescribed present-day sea surface temperatures (SST) and aerosol and precursor emissions from Lamarque et al. (2010) for $5 \mathrm{yr}$ plus 3-month spin up, and results from the last 5-yr are used in the analysis. All simulations have been carried out at $2.5^{\circ} \times 1.9^{\circ}$ horizontal resolution with 30 vertical levels. In the control case we use the LP05 and BN09 parameterizations in CAM5 including the competition between homogeneous and heterogeneous nucleation (i.e., "combined simulations", denoted below as LP and BN, respectively). Two additional sets of simulations were performed: pure homogeneous freezing (hereafter as LPhom and BNhom, respectively), and pure heterogeneous freezing (hereafter as LPhet and BNhet, respectively), for LP05 and BN09 parameterizations by turning off their representation of heterogeneous or homogeneous nucleation, respectively. Table 1 gives the list of simulations carried out. We note that ice formation in mixed-phase clouds discussed in Sect. 2.3 keeps the same between all these simulations.

The annual and zonal mean mass and number concentrations of mineral dust in the accumulation mode with the size (diameter) range of $0.1-1 \mu \mathrm{m}$ and in the coarse mode with the size (diameter) range of $1-10 \mu \mathrm{m}$ are shown in Fig. 1. About $90 \%$ of the total dust mass is in the coarse mode, while the accumulation mode dust dominates the total dust number concentration (Liu et al., 2012). Accumulation mode dust number concentration is in the range of $0.1-1.0 \mathrm{~cm}^{-3}$ in the $\mathrm{NH}$ upper troposphere $(100-300 \mathrm{hPa})$, where coarse mode dust number concentration is one order of magnitude lower. Dust is uplifted from the NH subtropics and midlatitude sources to the middle and upper troposphere and transported towards the Arctic in the upper troposphere. The dust number concentration in the upper troposphere agrees reasonably well with the model result by Hendricks et al. (2011). As we noted in Sect. 2, dust number concentration is used as an input for the heterogeneous nucleation formulations in LP05 and BN09.

An offline (box model) comparison between the LP05 and BN09 parameterizations for the pure homogeneous nucleation case done by Barahona and Nenes (2008) showed that the two parameterizations give similar ice number concentrations at cirrus temperatures less than $-40^{\circ} \mathrm{C}$ and updraft velocity less than $1 \mathrm{~m} \mathrm{~s}^{-1}$. The comparison of in-cloud ice crystal number concentration (Ni) for LPhom and BNhom is shown in Fig. 2 (middle panel). We can see that distribution patterns of Ni from LPhom and BNhom cases are similar, with higher Ni in the Southern Hemisphere (SH) and in the tropics. Both LPhom and BNhom cases predict $\mathrm{Ni}$ higher than $500 \mathrm{~L}^{-1}$ in the tropical tropopause and in $\mathrm{SH}$. $\mathrm{Ni}$ is reduced at warmer temperatures in the middle troposphere $(300-500 \mathrm{hPa})$ with values of $20-100 \mathrm{~L}^{-1}$, consistent with the nucleation rate reduction with increasing temperatures for homogeneous ice nucleation (Koop et al., 2000; Pruppacher and Klett, 1997) and aggregational growth of small ice crystals during the gravitational sedimentation from above. In the lower troposphere $(700-850 \mathrm{hPa}) \mathrm{Ni}$ increases to $100-200 \mathrm{~L}^{-1}$ in storm track regions due to the ice nucleation in mixed-phase clouds.

To compare BN09 and LP05 under the same condition, we turn off the soot contribution to IN number in BN09 (i.e., only dust particles can act as IN in both LP05 and BN09). An offline (box model) comparison showed that heterogeneous IN number concentration from CNT-based spectrum is typically a few times higher than that from the PDA08 (Barahona and Nenes, 2009a) with the same input of aerosols. As shown in Fig. 2 (lower panel), Ni calculated from BNhet with PDA08 is in the range of $10-50 \mathrm{~L}^{-1}$ in the upper troposphere regime, much lower than that $\left(100-300 \mathrm{~L}^{-1}\right)$ in the NH midlatitudes from LPhet. The higher Ni $\left(100-300 \mathrm{~L}^{-1}\right)$ in the subtropical and mid-latitudes of $\mathrm{NH}$ in LPhet is associated with the Saharan and Asian dust. The different Ni between LPhet and BNhet is due to the different formulations of IN number concentration (i.e., the CNT method in LPhet and the PDA08 in BNhet) even though they have the input of almost the same dust number concentrations between the two simulations (not shown).

Ice crystals formed from heterogeneous nucleation can inhibit the subsequent homogeneous nucleation through water vapor consumption in the cloud parcel. Offline comparison by Barahona and Nenes (2009b) showed that the limiting heterogeneous IN number $\left(N_{\text {lim }}\right)$ that would completely inhibit homogeneous nucleation is lower in LP05 parameterization than that in BN09 parameterization (i.e., homogeneous nucleation is more easily prevented in LP05 parameterization) under the same IN number concentration. Therefore we expect that the occurrence frequency of homogeneous nucleation will be lower with the LP05 parameterization having both higher heterogeneous IN number concentration and lower $N_{\text {lim }}$ than the BN09 parameterization when both homogeneous and heterogeneous nucleation are allowed to occur and compete. As a result Ni will be lower with LP05 in regions where there is sufficient heterogeneous IN to inhibit the homogeneous nucleation. Indeed, this is the case. As shown in Fig. 2 (upper panel), $\mathrm{Ni}$ in the NH upper troposphere is significantly reduced (by up to a factor of 2) in LP compared to LPhom due to higher heterogeneous dust IN concentration (100-300 L ${ }^{-1}$ ) there from LP05 (lower panel), clearly indicating the inhibition of homogeneous nucleation by heterogeneous nucleation. There are no obvious changes between $\mathrm{BN}$ and $\mathrm{BNhom}$ due to the lower heterogeneous dust IN number concentration $\left(10-50 \mathrm{~L}^{-1}\right)$ in the upper troposphere which does not have a strong impact on the homogeneous nucleation there, consistent with the study by Barahona et al. (2010).

Figure 3 shows the frequency distribution of homogeneous nucleation occurrence events in CAM5 (i.e., count as 1 if homogeneous nucleation occurs, otherwise 0 at each 3dimensional grid) for combined homogeneous and heterogeneous nucleation case and pure homogeneous nucleation 

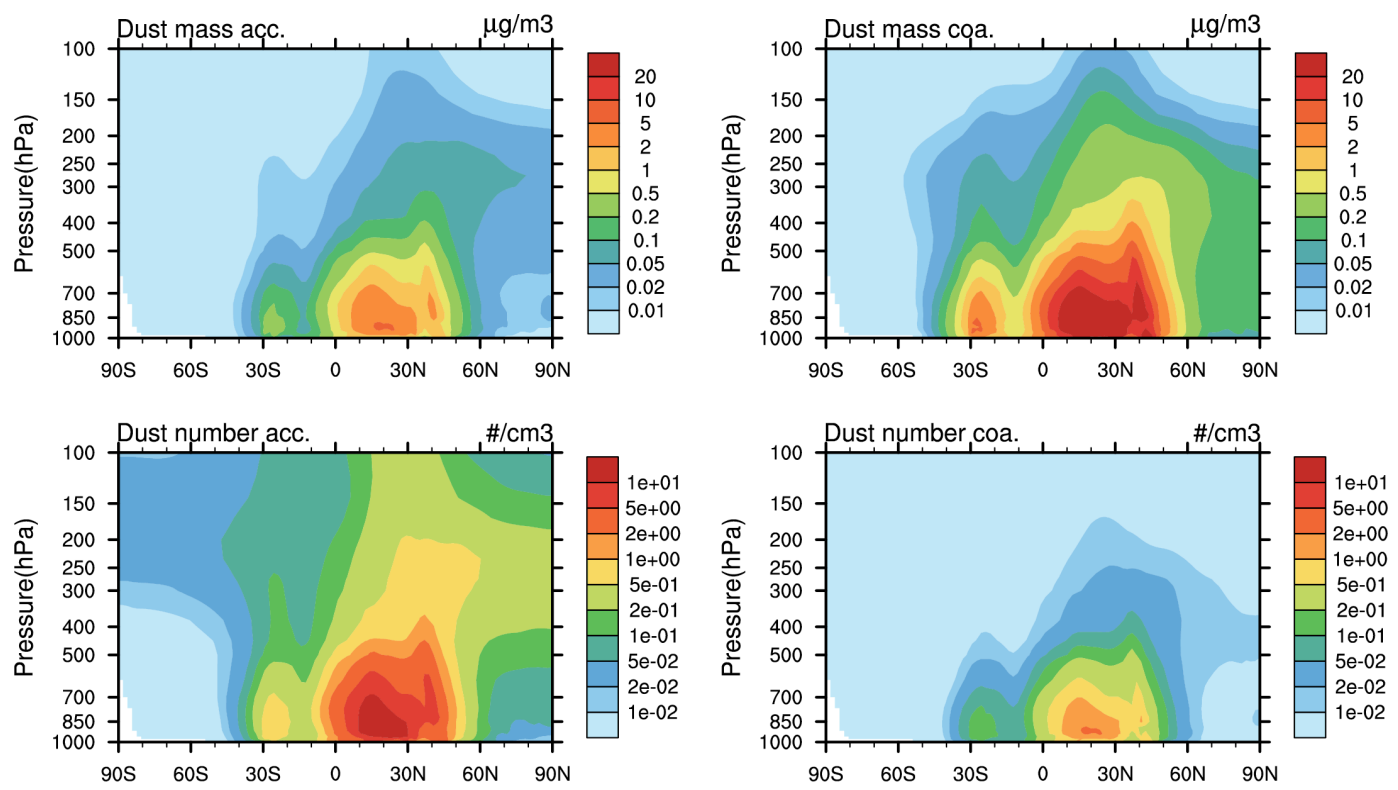

Fig. 1. Annual mean and vertical cross sections of mass (upper) and number (lower) concentrations of mineral dust in the accumulation mode $(0.1-1 \mu \mathrm{m}$ diameter, left $)$ and in the coarse mode $(1-10 \mu \mathrm{m}$ diameter, right). Results are taken from the LP05 combined simulation and represent 5-yr averages.
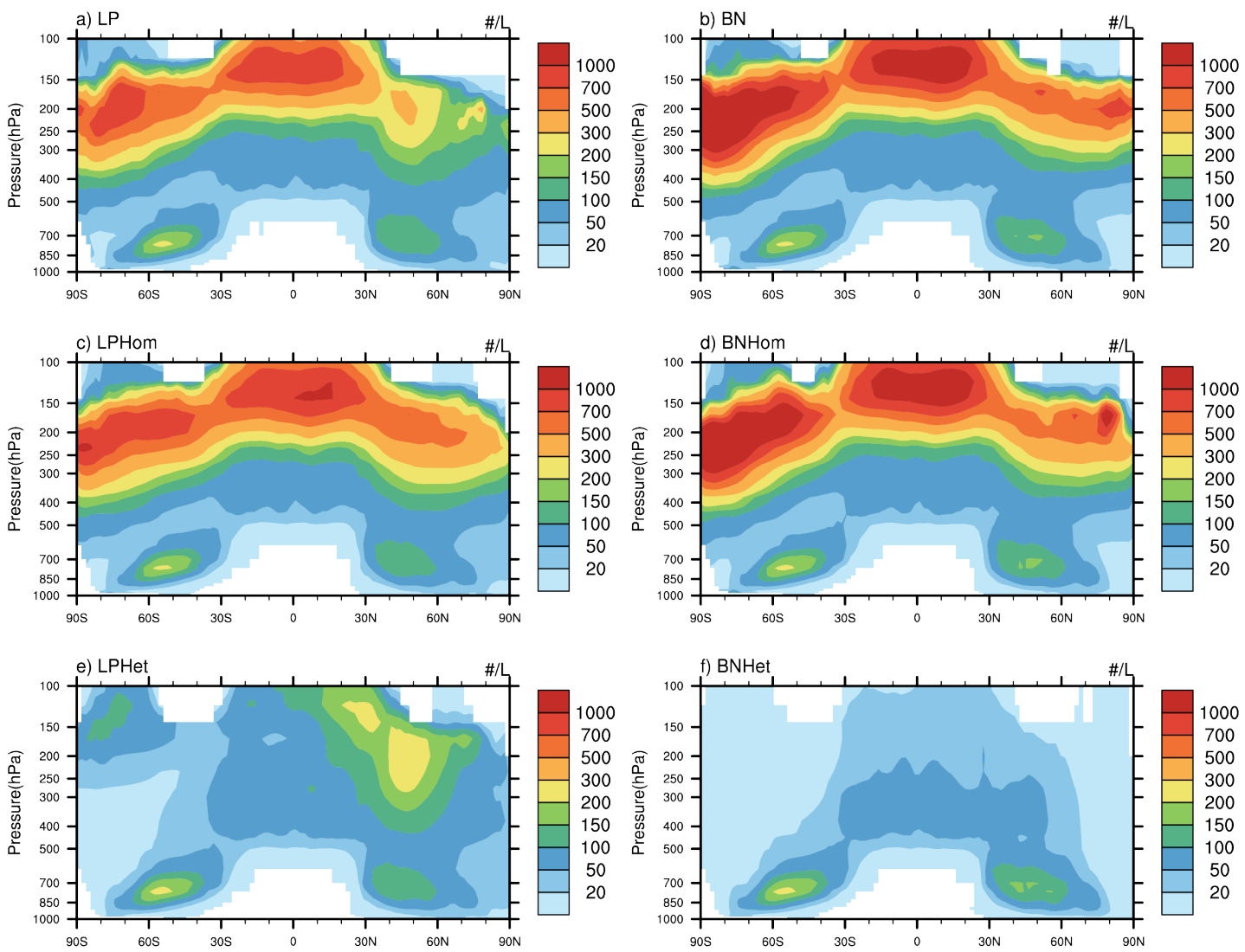

Fig. 2. Comparison of in-cloud ice crystal number concentration $\left(\mathrm{L}^{-1}\right)$ with LP05 (left) and BN09 (right) parameterizations for the combined homogeneous and heterogeneous nucleation (upper), pure homogeneous nucleation (middle), and pure heterogeneous nucleation (lower) simulations in CAM5. 

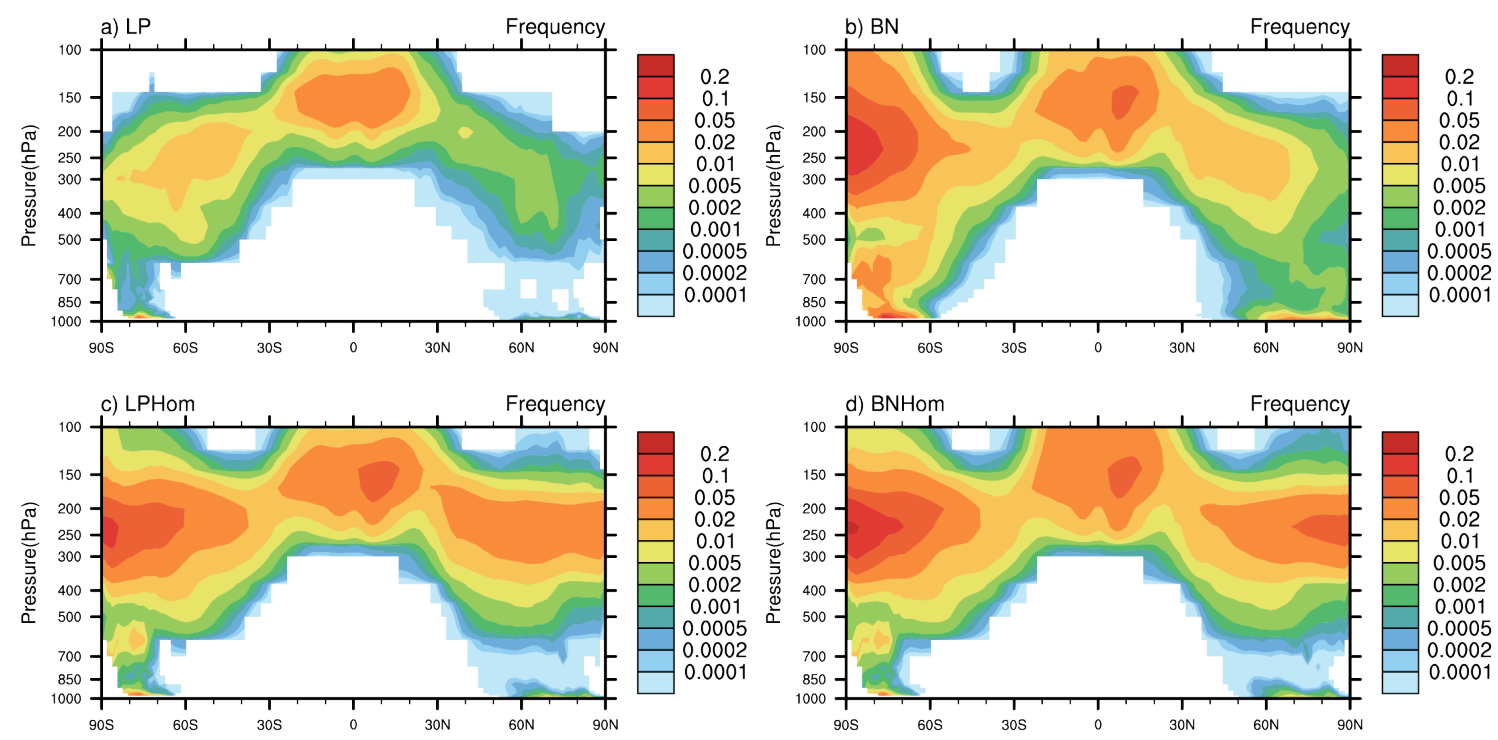

Fig. 3. Frequency distribution of homogeneous nucleation occurrence events in CAM5 for combined homogeneous and heterogeneous nucleation case (upper) and pure homogeneous nucleation case (lower) with LP05 (left) and BN09 (right) parameterizations.
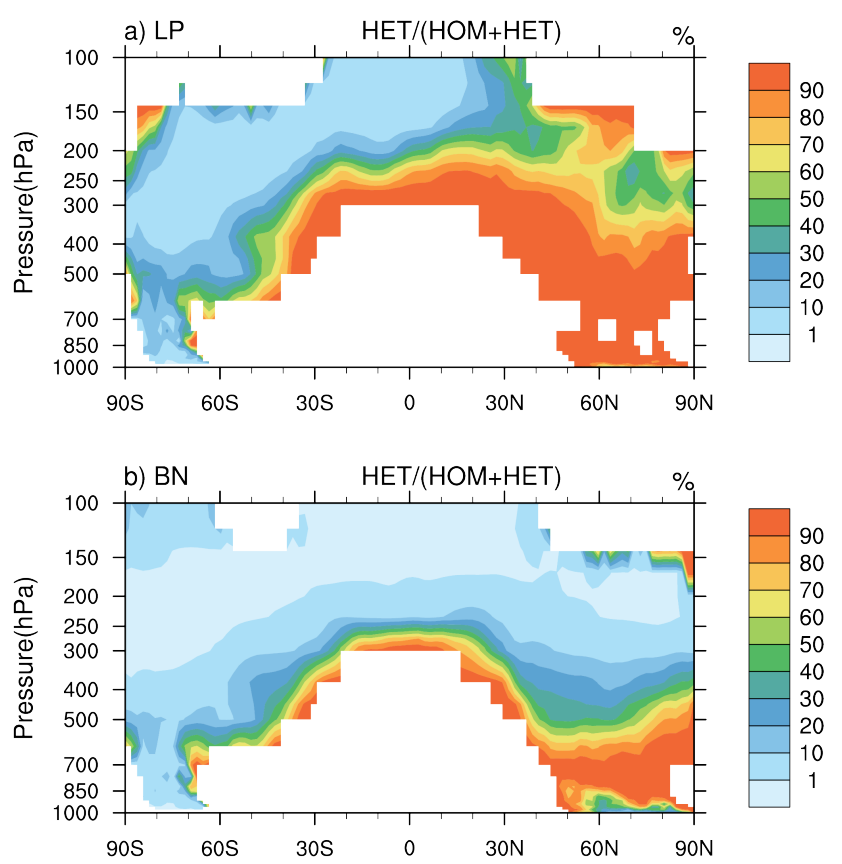

Fig. 4. Percentage contribution from heterogeneous ice nucleation to total ice crystal number concentration diagnosed in the ice nucleation parameterizations for the combined LP and BN cases.

case. We can see that the frequency of occurrence of homogeneous nucleation is similar for LPhom and BNhom case (lower panel). Heterogeneous IN reduce the frequency of homogeneous nucleation significantly for LP05 parameterization (upper panel), due to its higher heterogeneous IN number concentration and lower $N_{\text {lim }}$, while the reduction is evident only in the NH high-latitudes for BN09.
Figure 4 shows the percentage contribution of ice crystals from heterogeneous ice nucleation to total ice number diagnosed in the ice nucleation parameterizations for the combined LP and BN cases. We can see that homogeneous nucleation is the dominant contributor to $\mathrm{Ni}$ in the upper troposphere in the tropics and in the $\mathrm{SH}$, and contribution from heterogeneous nucleation is much smaller there $(<10 \%)$. In both LP and BN simulations, heterogeneous IN concentration is not high enough to completely turn off the occurrence of homogeneous freezing there. In the NH heterogeneous nucleation becomes more important especially for the LP case. The contribution of heterogeneous nucleation to total ice crystal number can reach over $50 \%$ for the LP case due to the larger IN number from the CNT. The contribution from heterogeneous nucleation is less than $10 \%$ (and mostly less than $1 \%$ ) in the upper troposphere for the BN case. Using the probability distributions of $\mathrm{RH}_{\mathrm{i}}$ measured during the INCA campaign, Haag et al. (2003) suggested that in situ cirrus clouds in the $\mathrm{NH}$ midlatitudes were likely formed from a combination of homogeneous and heterogeneous nucleation processes, whereas SH midlatitude cirrus clouds were dominated by the homogeneous nucleation. These INCA results appear to support the LP05 parameterization more than the BN09 parameterization with the heterogeneous IN spectrum of Phillips et al. (2008). We note that the relative importance of ice nucleation mechanisms depends on the in-cloud updraft velocity. If there was a high updraft velocity bias in CAM5, reducing the bias would make it easier for IN to prevent $\mathrm{RH}_{\mathrm{i}}$ from reaching the threshold values for the initiation of homogeneous nucleation, and thus increase the importance of IN from PDA08 on the overall ice crystal number. This will produce larger differences between BNhom 

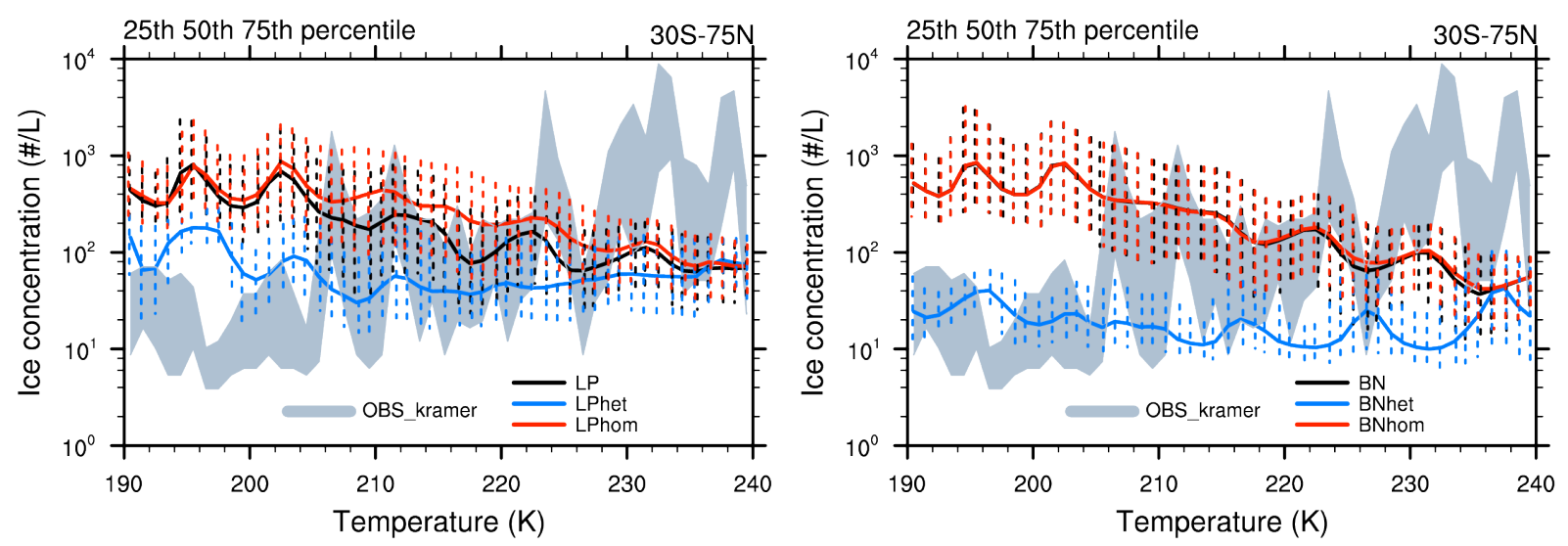

Fig. 5. In-cloud ice crystal number concentration $\left(\mathrm{L}^{-1}\right)$ versus temperature. Model results are sampled every 3 hours over tropical, midlatitude and Arctic regions including the observation locations reported in Krämer et al. (2009). The 50\% percentile (solid line), $25 \%$ and $75 \%$ percentiles (error bar) are shown for each $1 \mathrm{~K}$ temperature bins.

and $\mathrm{BN}$ results and improve the agreement of $\mathrm{BN}$ results with the INCA observations.

\section{Comparison of model results with observations}

Krämer et al. (2009) collected an extensive aircraft observational dataset in the temperature range of $183-240 \mathrm{~K}$. We compare model simulations against this dataset for pure homogeneous, pure heterogeneous and combined cases with LP05 and BN09 parameterizations. We output modeled incloud $\mathrm{Ni}$ every $3 \mathrm{~h}$ and bin them into $1 \mathrm{~K}$ interval of temperatures from 190 to $240 \mathrm{~K}$ (i.e., in the cirrus cloud regime) in the upper troposphere from $30^{\circ} \mathrm{S}$ to $75^{\circ} \mathrm{N}$. The range between 25th and 75th percentiles of modeled $\mathrm{Ni}$ within each temperature bin is shown in Fig. 5. The most distinctive feature of Fig. 5 is that observed Ni tends to increase with increasing temperature for the whole temperature range. $\mathrm{Ni}$ is in the range of $\sim 10-60 \mathrm{~L}^{-1}$ at temperatures below $205 \mathrm{~K}$. There have been studies to suggest that under these very low temperatures (i.e., near the tropical tropopause layer) aerosols rich with organic matter (e.g., Froyd et al., 2009) may become glassy, prevent homogeneous ice nucleation, and only allow heterogeneous nucleation to happen (Jensen et al., 2010; Murray et al., 2010). Barahona and Nenes (2011) also suggested that low Ni would result from the emergence of dynamical equilibrium states, favored at low temperatures. There is no obvious Ni trend in the temperature range between $205 \mathrm{~K}$ and $230 \mathrm{~K}$, and $\mathrm{Ni}$ is higher than that in the lower temperatures and within the range of $20 \mathrm{~L}^{-1}$ to a few hundred per liter. Above $230 \mathrm{~K}$, Ni increases with temperature and is frequently higher than $1000 \mathrm{~L}^{-1}$. This could be due to the shattering of large ice crystals at warmer temperatures, as suggested in Field et al. (2003) and Lawson (2011). Simulated Ni decreases with increasing temperature for pure homogeneous nucleation (LPhom and BNhom) and combined simulations ( $\mathrm{LP}$ and $\mathrm{BN}$ ) especially with BN09 pa- rameterization, consistent with the predominance of homogeneous nucleation. Ni from LPhom is close to that from BNhom. Ni from LP is lower than that from LPhom especially in the NH mid-latitudes with temperatures between 205-230 K by up to a factor of 2 , because of the stronger effect of heterogeneous ice nucleation in the LP05 parameterization than in BN09 (Fig. 4). Ni from BN is almost the same as BNhom due to the low heterogeneous IN concentration from the PDA08 spectrum. Ni from pure homogeneous (LPhom and BNhom) and combined simulations ( $\mathrm{LP}$ and $\mathrm{BN}$ ) overestimates observed $\mathrm{Ni}$ by a factor of $10-100$ in the temperature range of 190-205 K, while in the temperature range of 205-230 K, $\mathrm{Ni}$ from combined simulations is closer to the observed values. Compared to pure homogeneous and combined nucleation simulations, pure heterogeneous nucleation simulation with the BN09 parameterization (BNhet) shows better agreement with the observation in the temperature range of 190$205 \mathrm{~K}$, although it is not clear if the heterogeneous IN spectrum (PDA08) used in BNhet can be extrapolated to such low temperature regime. Ni from pure heterogeneous nucleation simulations (LPhet and BNhet) is too low $\left(20-40 \mathrm{~L}^{-1}\right)$ in the temperature range of $205-230 \mathrm{~K}$ compared to the observational data. LPhet which is based on CNT gives a higher $\mathrm{Ni}$ than BNhet which is based on PDA08 in the whole temperature range. The above comparison is consistent with the assertion that homogeneous ice nucleation is not able to explain the very low $\mathrm{Ni}$ in the low temperature range of less than $\sim 205 \mathrm{~K}$ near the tropical tropopause, and pure heterogeneous nucleation may dominate there (Jensen et al., 2010). The low Ni in cirrus clouds at these temperatures may also be due to the occurrence of "dynamical equilibrium" states between ice production and sedimentation loss (Barahona and Nenes, 2011). However, pure heterogeneous nucleation on dust with both LP05 and BN09 parameterization would not be able to explain observed Ni concentrations $\left(\sim 100 \mathrm{~L}^{-1}\right)$ in the temperature range of $205-230 \mathrm{~K}$, even in the LPhet 

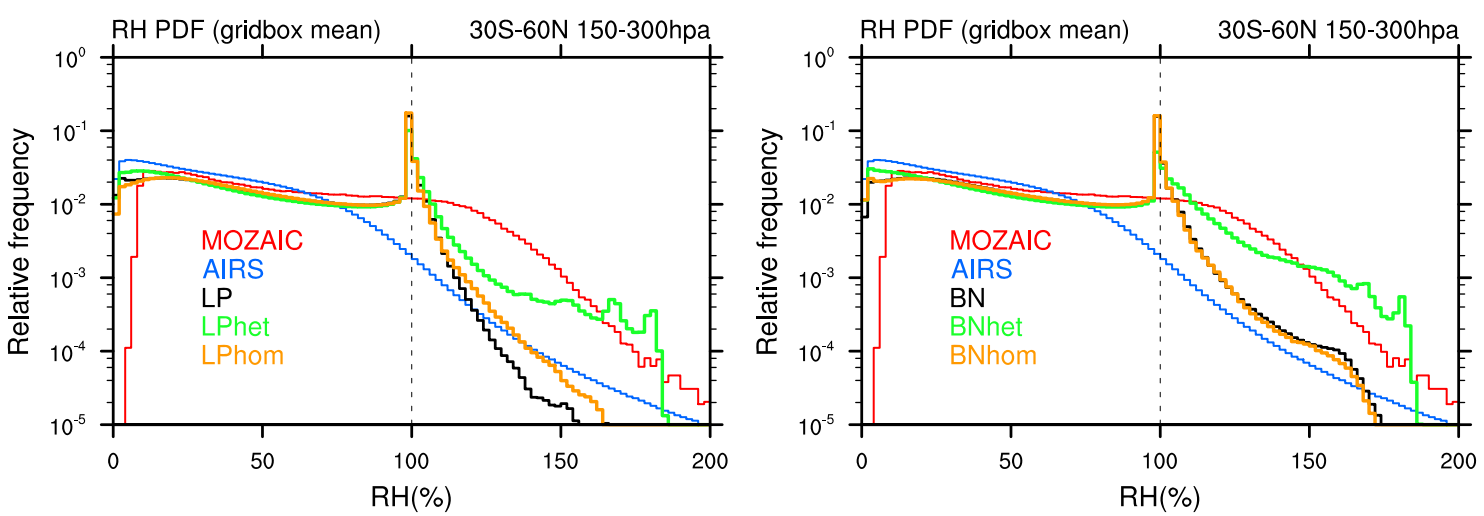

Fig. 6. Probability distribution frequency (PDF) of relative humidity in $150-300 \mathrm{hPa}$ from $30^{\circ} \mathrm{S}$ to $60^{\circ} \mathrm{N}$ from pure homogeneous, pure heterogeneous and combined nucleation simulations for LP05 (left) and BN09 (right) parameterizations, in comparison with humidity observations in the upper troposphere from the Measurements of Ozone, Water Vapor, Carbon Monoxide and Nitrogen Oxides by Airbus In-Service Aircraft (MOZAIC) and from the Atmospheric Infra-Red Sounder (AIRS) satellite.

simulation with CNT. This indicates that homogeneous nucleation is often the dominant ice nucleation mechanism in this temperature range. Considering the large fluctuation of observed $\mathrm{Ni}$ at a given temperature in this temperature range, heterogeneous nucleation may still have important effects during many cloud events, especially at low cooling rates.

Ice supersaturation is the driver of ice nucleation, and the level and distribution thereof gives insight on the relative importance of freezing mechanisms (e.g., Haag et al., 2003). We compare the probability distribution of relative humidity with respect to ice, $\mathrm{RH}_{\mathrm{i}}$, in $150-300 \mathrm{hPa}$ from $30^{\circ} \mathrm{S}$ to $60^{\circ} \mathrm{N}$ from instantaneous model output with pure homogeneous, pure heterogeneous and combined nucleation for LP05 and BN09 parameterizations, respectively. The modeled $\mathrm{RH}_{\mathrm{i}}$ is compared in Fig. 6 with humidity observations in the upper troposphere from the Measurements of Ozone, Water Vapor, Carbon Monoxide and Nitrogen Oxides by Airbus In-Service Aircraft (MOZAIC) project (Gierens et al., 1999) and from the Atmospheric Infra-Red Sounder (AIRS) satellite (Gettelman et al., 2006a). Both observed probability distributions of $\mathrm{RH}_{\mathrm{i}}$ from MOZAIC and AIRS show exponential decreases with increasing of RH. Note that MOZAIC may be subject to compressional heating artifacts (inflating the $\mathrm{RH}$ ), and may also be biased towards cloud-free conditions since pilots might avoid passages through thick cirrus layers. AIRS with a large RH uncertainty ( $20 \%)$ suffers from its $2-3 \mathrm{~km}$ vertical weighting function that may reduce the $\mathrm{RH}$ and the frequency of occurrence of thin supersaturated layers (Gettelman et al., 2006b). The all-sky model results can be biased towards low supersaturations owing to the water vapor deposition on ice crystals to remove supersaturations inside clouds for CAM5 with a large model time step of $30 \mathrm{~min}$. Indeed, the peak in frequency at $100 \% \mathrm{RH}_{\mathrm{i}}$ in the simulations is due to cloud points that are not sampled by MOZAIC or AIRS. Modeled supersaturation for pure homogeneous and combined nucleation with the BN09 parameterization (BN- hom and $\mathrm{BN}$ ) is higher than AIRS and lower than MOZAIC. Results from BNhom and BN are similar. Model simulations with the LP05 parameterization (LPhom and LP) underestimate the occurrence frequency of $\mathrm{RH}_{\mathrm{i}}$ larger than $\sim 120$ $140 \%$. As shown in Fig. 6, with the decrease of Ni from pure heterogeneous nucleation simulations (LPhet and $\mathrm{BN}$ het), occurrence frequency of high ice supersaturation is significantly increased. The low $\mathrm{Ni}\left(20-50 \mathrm{~L}^{-1}\right)$ in the upper troposphere from BNhet simulation could not consume water vapor efficiently by depositional growth of ice crystals and thus occurrence frequency of ice supersaturation from this simulation is larger than that from MOZIAC at $\mathrm{RH}_{\mathrm{i}} \sim 150$ $180 \%$. We note that low $\mathrm{Ni}$ (and thus small surface area of ice crystals) has been used to explain the persistent high supersautration in cold cirrus clouds (Murray et al., 2010; Peter et al., 2006).

Number concentration and size distribution of ice particles were routinely measured over the US Department of Energy Atmospheric Radiation Measurement (ARM) Southern Great Plains (SGP) site $\left(36.6^{\circ} \mathrm{N}, 97.5^{\circ} \mathrm{W}\right)$ from December 2009 to June 2010 during the SPartICus campaign (http://campaign.arm.gov/sparticus/). The suite of cloud particle probes included a 2D-S probe (Lawson et al., 2006), which was equipped with probe tips that reduced shattering and a post-processing algorithm designed to remove residual shattered particles (Lawson, 2011). SPartICus provides relatively long-term statistics ( $\sim 150 \mathrm{~h}$ of in situ data) of concentrations of ice particles in cirrus. A recent comparison between historical and SPartICus measurements in deep cirrus shows that SPartICus data typically contain lower concentrations of small $(<\sim 50 \mu \mathrm{m})$ ice particles, particularly near cloud base where large particles contribute the most to shattering (Lawson, 2011). Figure 7 shows the probability distribution of in-cloud ice number concentrations from SPartICus 



Fig. 7. Probability distribution frequency (PDF) of in-cloud ice number concentration $\left(\mathrm{L}^{-1}\right)$. Model results are sampled every $3 \mathrm{~h}$ and interpolated into the field measurement site location $\left(36.6^{\circ} \mathrm{N}, 97.5^{\circ} \mathrm{W}\right)$. All data are sampled over $7 \mathrm{~km}$.

data obtained during January to June $2010 .^{1}$ The most frequently observed $\mathrm{Ni}$ is in the range of about $10-200 \mathrm{~L}^{-1}$, although ice number concentrations larger than $1000 \mathrm{~L}^{-1}$ are also observed in a few occasions.

To compare with the aircraft measurements collected over the SGP area during the SPartICus campaign, we sampled instantaneous ice crystal number concentrations over the SGP site (interpolated using values in four GCM grid-boxes closest to the site) every three hours from January to June from 5 -yr simulations for different cases listed in Table 1. As most of the aircraft measurements were collected above $500 \mathrm{hPa}$, only samples above this level are considered in the analysis. All LP05 model simulations overestimate observed frequencies for $\mathrm{Ni}$ higher than $\sim 100 \mathrm{~L}^{-1}$, and underestimate observed frequencies for Ni less than $20-40 \mathrm{~L}^{-1}$. This is also the case for $\mathrm{BN}$ and BNhom. BNhet produces two modes in the probability distribution: one at $10 \mathrm{~L}^{-1}$ and another at $200-400 \mathrm{~L}^{-1}$. The lower Ni mode is due to the heterogeneous ice nucleation, while the higher mode is due to the convective detrainment, which also contributes to the occurrence of $\mathrm{Ni}$ at $200-400 \mathrm{~L}^{-1}$ for other cases (not shown). These comparisons suggest that homogeneous nucleation may play an important role in cirrus clouds to produce the high frequency of Ni higher than $100 \mathrm{~L}^{-1}$ over the ARM SGP site during the SPartICus. However model simulations underestimate the frequencies of occurrence for Ni less than $40 \mathrm{~L}^{-1}$ except for the BNhet simulation. This may indicate that CAM5 with large horizontal and vertical grid sizes may underestimate the growth processes of ice crystals by aggregation and/or rimming, which can reduce the ice number concentration in clouds (Spichtinger and Gierens, 2009a, b). Although LP and LPhet modeled histograms agree better with the observations than that of LPhom, a conclusion on the dominant role of heterogeneous nucleation mode during the SPartICus is still premature due to the discrepancies between model simulations and observations. Future analysis will evaluate

1 The SPartICus data used in this analysis are considered preliminary. However, final processing of the data is not expected to significantly alter the results shown here. the model representation of sub-grid updraft velocity (cooling rate), which is critical for the occurrence of homogeneous nucleation, and separate the in situ cirrus cases from the convective anvil cirrus cases in the comparison of model results and observations.

\section{Atmospheric impacts}

In this section, we will examine the impact of heterogeneous IN on upper tropospheric air temperature, specific humidity, and cloud properties by comparing simulations between the pure homogeneous nucleation and the combined homogeneous and heterogeneous nucleation simulations. Figure 8 shows latitude-pressure cross sections of annual mean $\mathrm{Ni}$ (grid-box average), IWC (grid-box average), cloud cover, temperature, and specific humidity from the LP simulation and differences of these variables between LPhom and LP. There is a statistically significant increase in $\mathrm{Ni}$ at the $90 \%$ level of the Student's t-test in LPhom compared to LP owing to the high number of heterogeneous IN in the $\mathrm{NH}$ midlatitudes from dust sources in North African and Asian deserts (see Fig. 1). Compared to LP, IWC in the NH upper troposphere in LPhom is increased by $20 \%$ due to smaller ice crystal sizes and slower sedimentation from the iceproducing layers. The strong increase in $\mathrm{Ni}$ enhances cloud cover in the NH midlatitudes by $2-5 \%$. Tropical upper tropospheric temperature increases by $\sim 0.5 \mathrm{~K}$ due to the longwave radiative heating from the increased presence of cirrus. Upper tropospheric water vapor generally increases by 10 $20 \%$. The higher tropical tropopause temperature increases the water vapor saturation pressure, and this together with reduced sedimentation of cloud ice allows more water vapor to be transported to the lower stratosphere (Rosenfield et al., 1998). Thus specific humidity in the lower stratosphere is increased by $\sim 10 \%$. Liu et al. (2009) and Hendricks et al. (2011) found similar impacts on the upper tropospheric and lower stratospheric (UTLS) water vapor mixing ratio when the ice crystal number concentration in cirrus clouds is changed. In comparison, the difference in $\mathrm{Ni}$ 

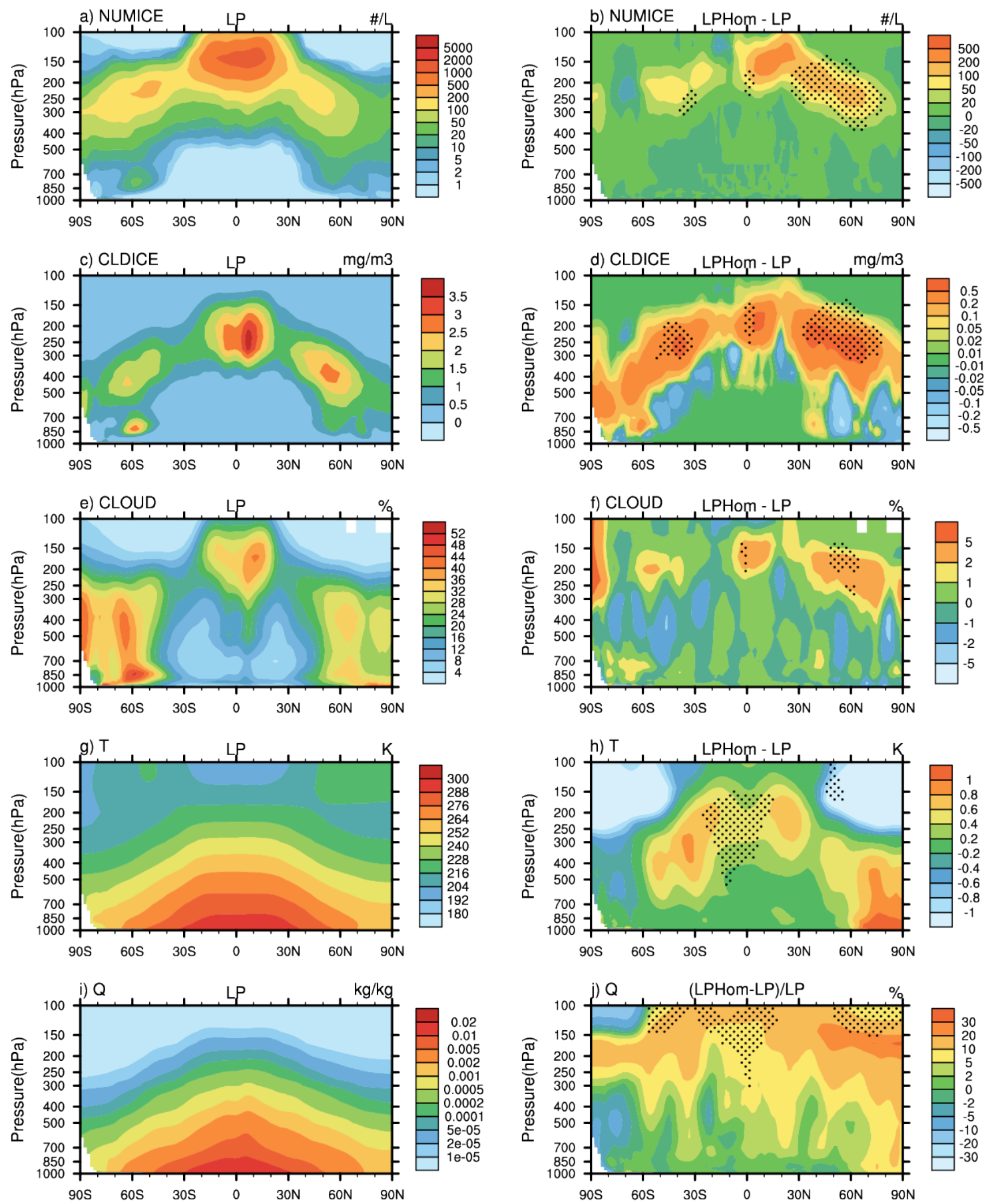

Fig. 8. Latitude-pressure cross sections of annual mean Ni (grid-box average), IWC (grid-box average), cloud cover, temperature, and specific humidity from combined ice nucleation simulation (left) and differences of these variables between pure homogeneous and combined nucleation simulations (right) for the LP05 parameterization in CAM5. Differences significant at the $90 \%$ level of the Student's t-test are depicted by dots.

between BNhom and $\mathrm{BN}$ is much smaller with maximum changes in the tropical tropopause about $50 \mathrm{~L}^{-1}$. Changes in IWC, cloud cover, temperature, and UTLS water vapor are statistically insignificant at the $90 \%$ level between BN and BNhom (not shown).
Figure 9 shows the annual and zonal mean shortwave cloud forcing (SWCF), longwave cloud forcing (LWCF), net cloud forcing (CF), high cloud cover (CLDHGH), ice water path (IWP), cloud-top ice effective radius (ACTREI), and column cloud ice number concentration (CDNUMI) from the 
Table 2. Global annual mean cloud properties from sensitivity simulations listed in Table 1 for liquid water path (LWP, $\mathrm{g} \mathrm{m}^{-2}$ ), ice water path (IWP, $\mathrm{g} \mathrm{m}^{-2}$ ), shortwave cloud forcing (SWCF, $\mathrm{W} \mathrm{m}^{-2}$ ), longwave cloud forcing (LWCF, $\mathrm{W} \mathrm{m}^{-2}$ ), total cloud cover (CLDTOT, \%), high cloud cover (CLDHGH, \%), and column ice number concentration (CDNUMI, $\times 10^{8} \mathrm{~m}^{-2}$ ).

\begin{tabular}{lccccccc}
\hline Case Name & LWP & IWP & SWCF & LWCF & CLDTOT & CLDHGH & CDNUMI \\
\hline LP & 46.9 & 18.3 & -53.0 & 29.5 & 65.4 & 42.5 & 4.82 \\
LPhom & 47.4 & 19.4 & -55.0 & 31.9 & 65.6 & 42.6 & 5.86 \\
LPhet & 45.3 & 17.2 & -46.3 & 22.6 & 62.1 & 38.8 & 1.34 \\
\hline BN & 47.1 & 17.8 & -52.9 & 28.8 & 64.5 & 41.1 & 5.75 \\
BNhom & 46.9 & 17.8 & -52.9 & 29.1 & 64.7 & 41.6 & 5.79 \\
BNhet & 44.6 & 15.4 & -43.8 & 18.6 & 61.0 & 37.5 & 0.67 \\
\hline
\end{tabular}

model simulations carried out in this study. Modeled SWCF, LWCF and CF are compared with satellite retrievals from the Clouds and the Earth's Radiant Energy System (CERES) (Wielicki et al., 1996), and CLDHGH with combined CloudSat and CALIPSO cloud fractions (Gettelman et al., 2010). Overall, SWCF from combined nucleation simulations (LP and $\mathrm{BN}$ ) agrees well with the observations, except in the tropics and subtropics where the SWCF is too strong, probably because of the too high ice crystal number concentration there in these simulations (Fig. 5). Noticeable differences in SWCF between different ice nucleation simulations are only in the tropics and subtropics. This is expected since SWCF in the extratropics is dominated from middle and low-level clouds. The SWCF differences reach $\sim 10 \mathrm{~W} \mathrm{~m}^{-2}$ between different simulations for both LP05 and BN09 parameterizations, with pure homogeneous nucleation simulations having the strongest (more negative) SWCF, followed by the slightly weaker SWCF from the combined nucleation simulations and then weakest SWCF from the pure heterogeneous nucleation simulations. This is consistent with the lowest $\mathrm{Ni}$ from pure heterogeneous nucleation simulations, the smallest IWP, and the weakest SWCF. Similar differences between different simulations occur for LWCF, but expand to the extratropics, since cirrus clouds have an important contribution to LWCF globally. LWCF from different model simulations underestimates the observations in the midlatitudes. The net CF from all the model simulations for both LP05 and BN09 is stronger than observations in the tropics and subtropics. The net CF differences between different simulations are small due to the cancellation of SWCF and LWCF differences. The lowest $\mathrm{Ni}$ from the pure heterogeneous nucleation (LPhet and BNhet) results in the largest ice crystal size and highest sedimentation rate and thus the smallest IWP (Fig. 9b). The same is true for CLDHGH from BNhet which is lower by $\sim 10 \%$ than other two simulations (BN and $\mathrm{BN}$ hom) in the SH extratropics due to the lowest $\mathrm{Ni}$ from BNhet simulation (Fig. 9a). There is no obvious difference in the cloud-top ice effective radius except for the BNhet simulation which has a larger ice effective radius due to the lower $\mathrm{Ni}$ (Fig. 9b). The cloud-top ice effective radius is similar among the three simulations for LP05, although differences are much larger at lower cloud levels. Column ice number concentration from the pure homogeneous nucleation simulation is higher than that from the combined nucleation simulation especially in the NH midlatitudes for the LP05 parameterization, and both simulations are a few times higher than that from the pure heterogeneous nucleation simulation for both LP05 and BN09 parameterizations.

Table 2 gives the global and annual means of LWP, IWP, SWCF, LWCF, total and high cloud cover, and column ice number concentrations from different simulations. Comparing combined (LP) and pure homogeneous nucleation (LPhom) simulations, heterogeneous dust IN reduces the column ice number concentration by $20 \%$. This reduces global mean SWCF (less negative) by $2.0 \pm 0.1 \mathrm{~W} \mathrm{~m}^{-2}(1 \sigma$ uncertainty) and LWCF (less positive) by $2.4 \pm 0.1 \mathrm{~W} \mathrm{~m}^{-2}$, respectively for LP05. The net change in global mean cloud forcing (CF) is $-0.40 \pm 0.20 \mathrm{~W} \mathrm{~m}^{-2}$ (cooling). The SWCF and LWCF in the pure heterogeneous nucleation simulation (LPhet) are much weaker (by $6.7 \pm 0.2$ and $6.9 \pm 0.2 \mathrm{~W} \mathrm{~m}^{-2}$, respectively on the global mean) compared to the combined simulation, due to a factor of $\sim 4$ lower column ice number concentration. The column ice number concentration with BNhet is half of that with LPhet. Comparing combined simulation $(\mathrm{BN})$ and pure homogeneous nucleation (BNhom), heterogeneous dust IN has a negligible effect on the global mean SWCF, and reduce the global mean LWCF by $0.24 \pm 0.14 \mathrm{~W} \mathrm{~m}^{-2}$ (cooling). The SWCF and LWCF in the pure heterogeneous nucleation simulation (BNhet) are lower than the BN simulation by $9.1 \pm 0.2$ and $10.2 \pm 0.1 \mathrm{~W} \mathrm{~m}^{-2}$, respectively.

Figure 10 shows the annual and zonal mean distributions of net $\mathrm{CF}$ differences between the combined and pure homogeneous nucleation simulations (i.e., net $\mathrm{CF}$ changes due to the dust IN) and between the pure heterogeneous and combined nucleation simulations for LP05 and BN09. Table 3 gives the net $\mathrm{CF}$ changes averaged over different latitude bands. Statistically significant changes caused by the dust IN occur in the NH midlatitudes $\left(-1.81 \pm 0.47 \mathrm{~W} \mathrm{~m}^{-2}\right.$ for LP05 and $-0.39 \pm 0.20 \mathrm{~W} \mathrm{~m}^{-2}$ for BN09). The net CF changes between the pure heterogeneous and combined nucleation simulations are statistically significant in the tropics and in 

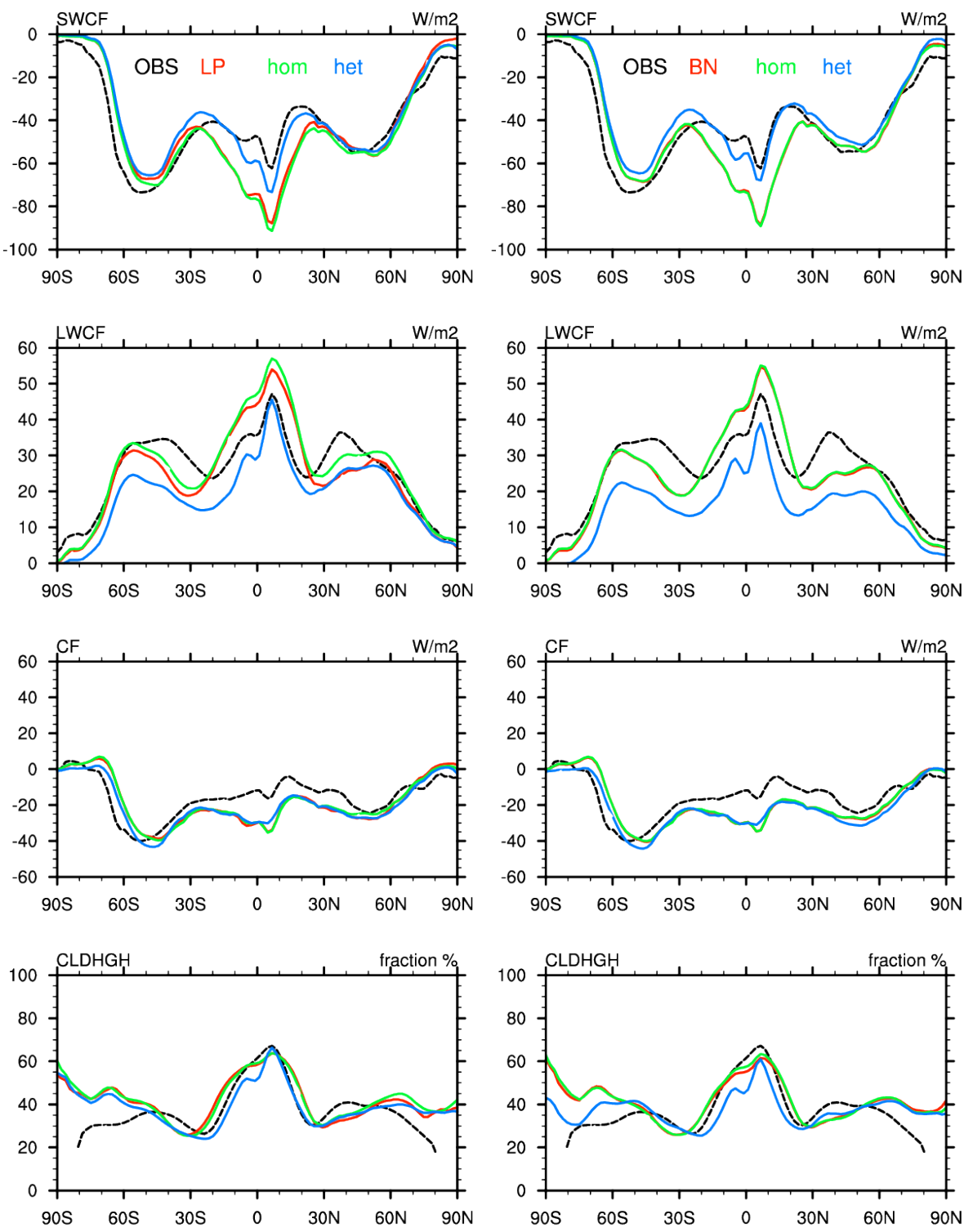

Fig. 9a. Annual and zonal mean distributions of shortwave cloud forcing (SWCF), longwave cloud forcing (LWCF), net cloud forcing (CF), and high cloud cover (CLDHGH) from different model simulations with LP05 (left) and BN09 (right) parameterizations. Black-dashed lines are from observations.

the SH for LP05 due to the low dust IN concentration there, while the net $\mathrm{CF}$ changes are significant at all latitude bands for BN09.

\section{Discussion and conclusions}

In this study the impact of heterogeneous dust IN on upper tropospheric cirrus clouds is investigated using CAM5 with two ice nucleation parameterization frameworks (LP05 and BN09). Both parameterizations consider the homogeneous and heterogeneous nucleation and competition between the two mechanisms. The heterogeneous IN concentration from
LP05 is based on the CNT, and is higher than that from BN09, which is based on the PDA08 spectrum. The difference is larger in the $\mathrm{NH}$ upper troposphere (by up to a factor of ten) where mineral dust particles from deserts are more abundant. Because of the inhibition of homogeneous nucleation by heterogeneous dust IN, the frequency occurrence of homogeneous nucleation in the upper troposphere is substantially reduced in the $\mathrm{NH}$ compared with that from the pure homogeneous nucleation simulation in LP05. The impact of heterogeneous dust IN is much smaller in BN09 because of the lower dust IN concentration as predicted by the PDA08. As a result, the overall ice crystal number concentration is reduced by up to a factor of 2 in $\mathrm{NH}$ in the combined nucleation 

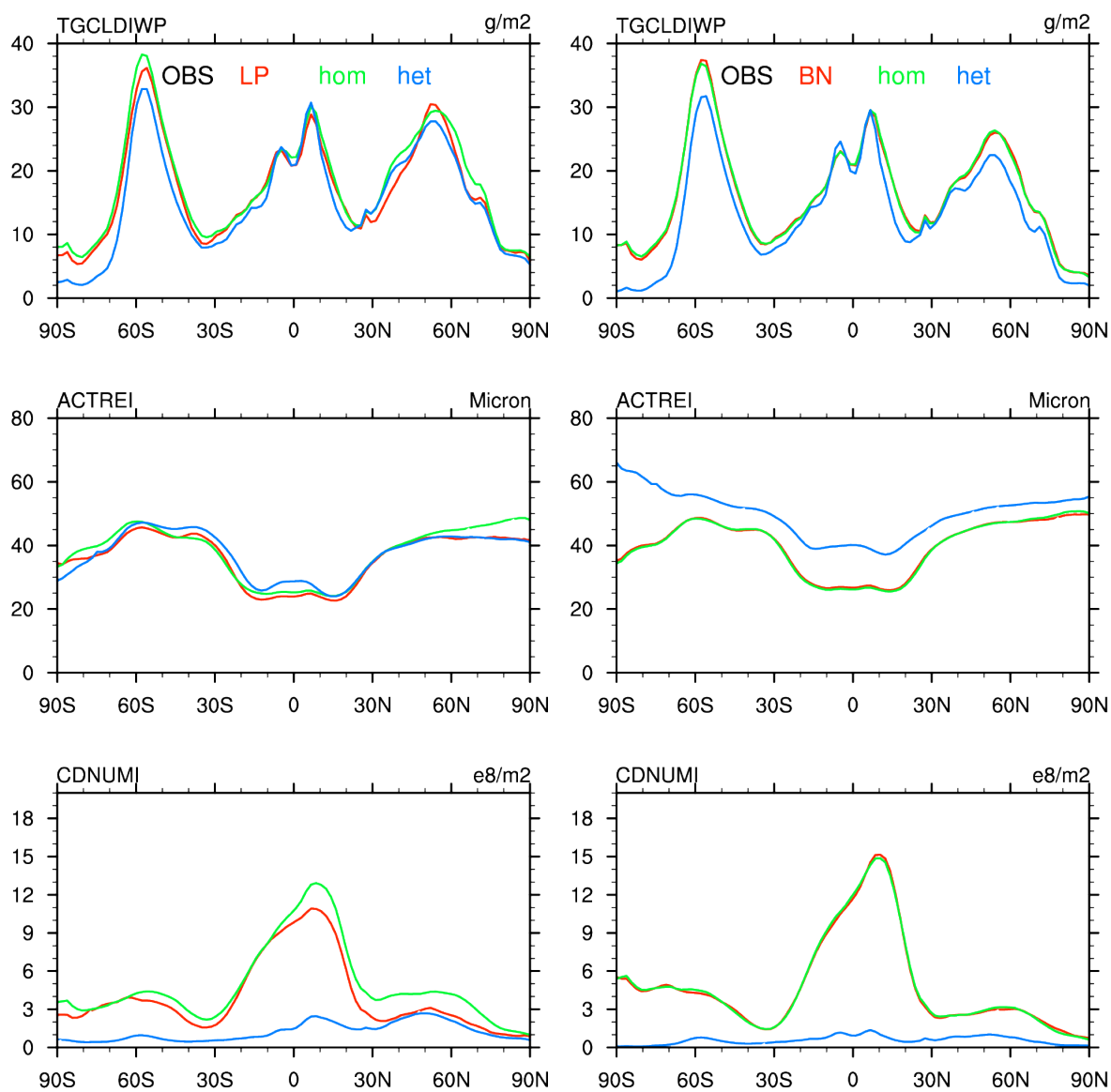

Fig. 9b. Same as Fig. 9a but for ice water path (IWP), cloud-top ice effective radius (ACTREI), and column cloud ice number concentration (CDNUMI).

Table 3. Global, tropical $\left(30^{\circ} \mathrm{S}-30^{\circ} \mathrm{N}\right)$, Northern Hemisphere $(\mathrm{NH})$ and Southern Hemisphere (SH), mid-latitude $\left(30-60^{\circ} \mathrm{S}\right.$ and $\left.30-60^{\circ} \mathrm{N}\right)$, and high-latitude $\left(60-90^{\circ} \mathrm{S}\right.$ and $\left.60-90^{\circ} \mathrm{N}\right)$ annual mean changes $(\Delta)$ of net cloud forcing $\left(\mathrm{CF}, \mathrm{W} \mathrm{m}^{-2}\right)$ between the combined and pure homogeneous nucleation simulations and between the pure heterogeneous and combined nucleation simulations for the LP05 and BN09 parameterizations. Standard deviations $( \pm \sigma)$ are estimated from means of each of $5 \mathrm{yr}$.

\begin{tabular}{rrrrrr}
\hline \multicolumn{1}{r}{ Case Name } & LP-LPhom & LPhet-LP & BN-BNhom & BNhet-BN \\
\hline Global & $-0.40 \pm 0.20$ & $-0.17 \pm 0.28$ & $-0.24 \pm 0.28$ & $-1.22 \pm 0.08$ \\
Tropics & $0.15 \pm 0.21$ & $0.78 \pm 0.24$ & $-0.25 \pm 0.52$ & $0.30 \pm 0.19$ \\
\multirow{4}{*}{ CF } & NH mid-latitudes & $-1.81 \pm 0.47$ & $0.10 \pm 0.29$ & $-0.39 \pm 0.20$ & $-2.29 \pm 0.28$ \\
NH high-latitudes & $-1.41 \pm 1.35$ & $-0.54 \pm 0.60$ & $-0.14 \pm 0.47$ & $-2.69 \pm 0.59$ \\
& SH mid-latitudes & $-0.15 \pm 0.81$ & $-1.44 \pm 0.85$ & $-0.08 \pm 0.68$ & $-2.19 \pm 0.47$ \\
& SH high-latitudes & $-0.45 \pm 0.11$ & $-4.48 \pm 0.37$ & $-0.34 \pm 0.24$ & $-5.85 \pm 0.40$ \\
\hline
\end{tabular}

simulation compared to the pure homogeneous nucleation simulation for LP05. Contribution of ice crystals nucleated from heterogeneous nucleation to total nucleated ice number concentration can reach over $50 \%$ in the NH from the LP05 parameterization compared to less than $10 \%$ globally for the BN09 parameterization.

We compare modeled cloud ice number concentration from different simulations with the two parameterizations with observations. Good agreement only occurs at tempera- tures lower than $205 \mathrm{~K}$ for the pure heterogeneous nucleation simulation with BN09 using the PDA08's heterogeneous IN spectrum. However, pure heterogeneous nucleation simulations give too low ice number concentrations at the temperature range of $205-230 \mathrm{~K}$, and thus homogeneous nucleation may play an important role in the ice formation. This is confirmed from the relatively long-term $(\sim 150 \mathrm{~h})$ statistics of cirrus clouds obtained at a NH midlatitude site during the SPartICus campaign, which shows the large frequency 

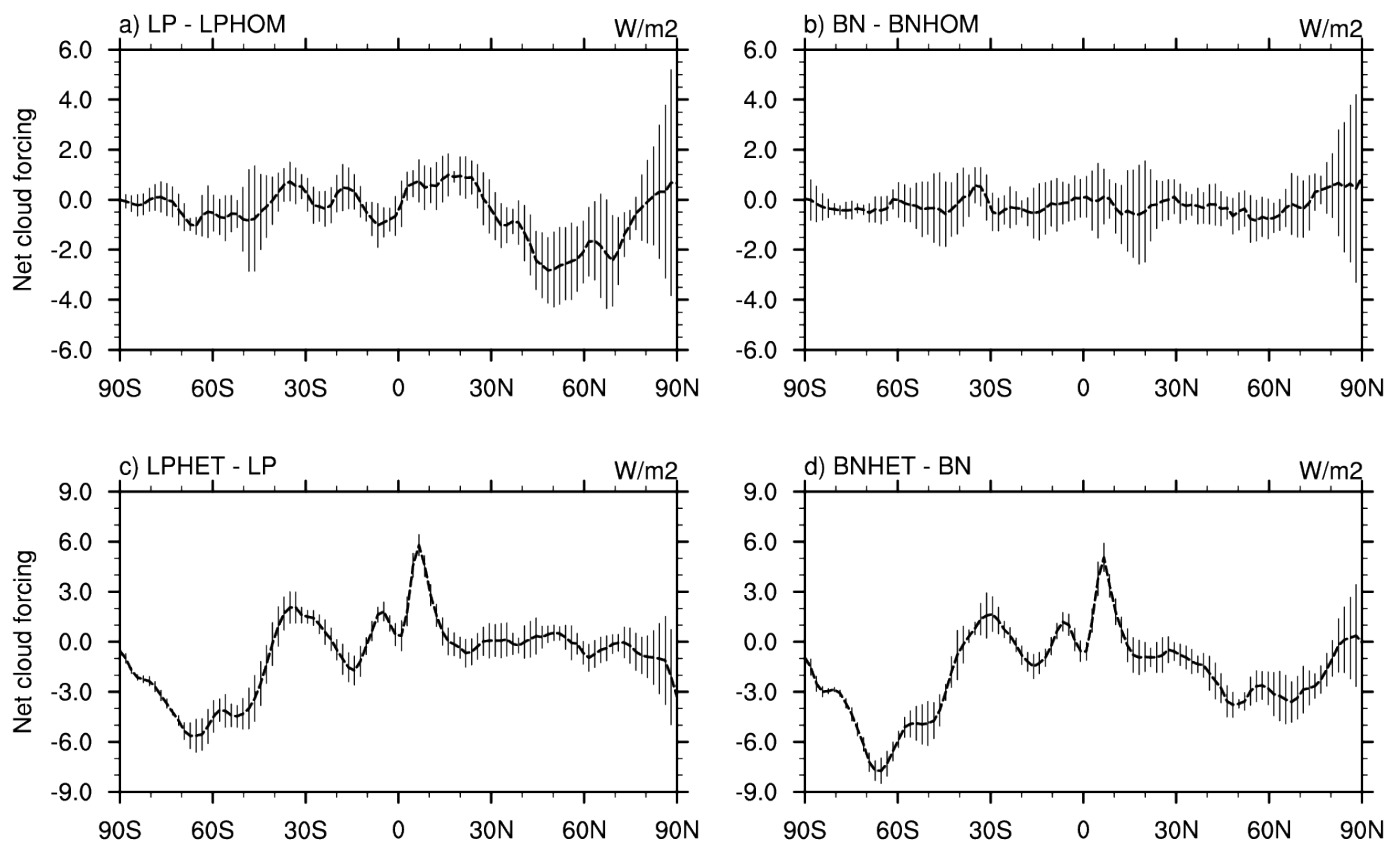

Fig. 10. Annual and zonal mean distributions of net cloud forcing (CF) differences between combined and pure homogeneous nucleation simulations (upper) and between pure heterogeneous and combined nucleation simulations (lower) with LP05 (left) and BN09 (right) parameterizations. The vertical bars overlaid on solid lines depict the ranges of the two standard deviations $(2 \sigma)$ estimated from the CF differences of each of $5 \mathrm{yr}$ at different latitudes.

$(41 \%)$ of high ice number concentrations $\left(>100 \mathrm{~L}^{-1}\right)$. However, the large fluctuation (by more than one order of magnitude) of observation data at a given temperature also suggest the role of heterogeneous nucleation affecting or completely inhibiting the homogeneous nucleation as well as the importance of aggregation and rimming of ice crystals. Model simulations with homogenous nucleation dominating the ice formation underestimate the occurrence frequency of ice number concentration lower than $40 \mathrm{~L}^{-1}$, while overestimate the frequency of ice number concentration higher than $100 \mathrm{~L}^{-1}$ during the SPartICus.

Heterogeneous dust IN may have a significant global impact on cloud radiative forcing (SWCF and LWCF) by $2 \mathrm{~W} \mathrm{~m}^{-2}$, ice water content by $20 \%$, and upper tropospheric water vapor mixing ratio by $10-20 \%$ if there is sufficient number of heterogeneous IN $\left(\sim 200 \mathrm{~L}^{-1}\right)$ in the upper troposphere. The net cloud forcing change is $-0.40 \pm 0.20 \mathrm{~W} \mathrm{~m}^{-2}$. However, with a small number of heterogeneous IN $\left(20-50 \mathrm{~L}^{-1}\right)$ in the upper troposphere the net cloud forcing change becomes statistically insignificant $\left(-0.24 \pm 0.28 \mathrm{~W} \mathrm{~m}^{-2}\right)$. These results highlight the importance of understanding the ice nucleation mechanisms and of quantifying the number concentrations and properties of heterogeneous IN. We note that the relative importance of heterogeneous IN on upper tropospheric cirrus clouds also depends on the cooling rate (i.e., vertical velocity) of air parcels in clouds. If the vertical velocity is sufficient high (e.g., larger than $0.5 \mathrm{~m} \mathrm{~s}^{-1}$ ) homogeneous nucleation may eventually take place after the heterogeneous nucleation and dominate the overall ice number concentration (e.g., Kärcher and Lohmann, 2003). The evaluation of modeled sub-grid vertical velocity with SPartICus remote sensing and in situ aircraft observations will be conducted in our next study.

Lohmann et al. (2008) also examined the competition effects between heterogeneous nucleation from dust aerosol and homogeneous nucleation from sulfate aerosol using the ECHAM5 model. They assumed that the homogeneous nucleation will be completely switched off (i.e., only heterogeneous nucleation can occur) when IN concentration is higher than a threshold value of $1 \mathrm{~L}^{-1}$, and homogeneous nucleation occurs elsewhere. By this they found a much stronger net $\mathrm{CF}$ cooling effect $\left(-2.0 \mathrm{~W} \mathrm{~m}^{-2}\right)$ due to dust IN than $-0.40 \pm 0.20 \mathrm{~W} \mathrm{~m}^{-2}$ obtained in our study. In our study, when the IN concentration is about $20 \mathrm{~L}^{-1}$ (as calculated from PDA08 in BNhet shown in Fig. 2), homogeneous nucleation still plays a dominant role in the combined simulation for the BN09 parameterization (Fig. 4). Only when the IN concentration is higher than $100 \mathrm{~L}^{-1}$ in the Northern Hemisphere (as calculated in LPhet shown in Fig. 2), the heterogeneous nucleation then becomes very important in the combined simulation for the LP05 parameterization (Fig. 4). The much lower IN threshold value assumed in Lohmann et al. (2008) to completely switch off the homogeneous nucleation can be the reason for the larger net CF cooling effects of dust IN found in Lohmann et al. (2008). This is confirmed from the significant reduction of ice crystal number 
concentration on the global scale in their combined simulation as compared to their pure homogeneous nucleation simulation and the similar ice crystal number in their combined simulation to that in their pure heterogeneous nucleation simulation as shown in Fig. 2 of Lohmann et al. (2008). The global annual mean vertically integrated ice crystal number is reduced by $47 \%$ in their combined simulation as compared to their pure homogeneous nucleation simulation (Table 2 of Lohmann et al., 2008), while in our study the reduction is only $18 \%$ for the LP05 parameterization and the reduction is only seen in the Northern Hemisphere (Fig. 2 and Table 2 of this study). This indicates a much greater (and a dominant) role of heterogeneous nucleation in the combined simulation of Lohmann et al. (2008). A comparison of the subgrid cloud updraft velocity between Lohmann et al. (2008) and this study will help to understand the sensitivity of ice nucleation to aerosols, which will be done in our future study.

Model evaluation with observations indicates several areas of future model improvement. The sub-grid features of ice supersaturation, and ice nucleation and growth need to be better represented in global climate models with horizontal grid sizes of $100 \mathrm{~km}$. These ice microphysics parameterizations need to be linked with the cloud macrophysics scheme in climate models. This can be achieved by implementing a statistical cloud macrophysics scheme (e.g., Kärcher and Burkhardt, 2008) into CAM3 (Wang and Penner, 2010) and CAM5 (M. Wang, personal communication, 2012), which will be evaluated with observation data. Further model improvement would also separate the prediction of cloud ice crystals by sources, such as the ice crystals formed from homogeneous nucleation, heterogeneous nucleation and from convective detrainment (Hendricks et al., 2011). BN09 ice nucleation parameterization will also be modified to account for the impact of pre-existing ice crystals on ice nucleation and to include ice nucleation on glassy aerosols (Murray et al., 2010) and on ammonium sulfate (Abbatt et al., 2006). As we find from this study, major differences in CAM5 simulations with LP05 (the default scheme in CAM5) and the new implemented BN09 are due to their different heterogeneous ice nucleation formulations. We note that BN09 has four IN spectra to choose. The comparison of these IN spectra on ice crystal number concentration and impact on cirrus clouds under the same BN09 framework will be presented in our future study.

Acknowledgements. Support for X. Liu was provided from the US Department of Energy (DOE), Office of Science, Atmospheric System Research (ASR) and Decadal and Regional Climate Prediction using Earth System Models (EaSM) Programs. Support for Donifan Barahona was provided by the NASA Modeling, Analysis and Prediction Program under WBS 802678.02.17.01.07. The Pacific Northwest National Laboratory is operated for DOE by Battelle Memorial Institute under contract DE-AC06-76RLO 1830.

Edited by: M. Krämer

\section{References}

Abbatt, J. P. D., Benz, S., Cziczo, D. J., Kanji, Z., Lohmann, U., and Mohler, O.: Solid ammonium sulfate aerosols as ice nuclei: A pathway for cirrus cloud formation, Science, 313, 1770-1773, doi:10.1126/science.1129726, 2006.

Barahona, D. and Nenes, A.: Parameterization of cirrus cloud formation in large-scale models: Homogeneous nucleation, J. Geophys. Res., 113, D11211, doi:10.1029/2007jd009355, 2008.

Barahona, D. and Nenes, A.: Parameterizing the competition between homogeneous and heterogeneous freezing in cirrus cloud formation - monodisperse ice nuclei, Atmos. Chem. Phys., 9, 369-381, doi:10.5194/acp-9-369-2009, 2009a.

Barahona, D. and Nenes, A.: Parameterizing the competition between homogeneous and heterogeneous freezing in ice cloud formation - polydisperse ice nuclei, Atmos. Chem. Phys., 9, 59335948, doi:10.5194/acp-9-5933-2009, 2009b.

Barahona, D., Rodriguez, J., and Nenes, A.: Sensitivity of the global distribution of cirrus ice crystal concentration to heterogeneous freezing, J. Geophys. Res., 115, D23213, doi:10.1029/2010JD014273, 2010.

Barahona, D. and Nenes, A.: Dynamical states of low temperature cirrus, Atmos. Chem. Phys., 11, 3757-3771, doi:10.5194/acp11-3757-2011, 2011.

Bigg, E. K.: The supercooling of water, Proc. Phys. Soc. London, 66B, 688-694, 1953.

Bretherton, C. S. and Park, S.: A New Moist Turbulence Parameterization in the Community Atmosphere Model, J. Climate, 22, 3422-3448, doi:10.1175/2008jcli2556.1, 2009.

Chen, J.-P., Hazra, A., and Levin, Z.: Parameterizing ice nucleation rates using contact angle and activation energy derived from laboratory data, Atmos. Chem. Phys., 8, 7431-7449, doi:10.5194/acp-8-7431-2008, 2008.

Chen, Y. L., DeMott, P. J., Kreidenweis, S. M., Rogers, D. C., and Sherman, D. E.: Ice formation by sulfate and sulfuric acid aerosol particles under upper-tropospheric conditions, J. Atmos. Sci., 57, 3752-3766, 2000.

Collins, W. D., Rasch, P. J., Boville, B. A., Hack, J. J., McCaa, J. R., Williamson, D. L., Briegleb, B. P., Bitz, C. M., Lin, S. J., and Zhang, M. H.: The formulation and atmospheric simulation of the Community Atmosphere Model version 3 (CAM3), J. Climate, 19, 2144-2161, 2006a.

Collins, W. D., Bitz, C. M., Blackmon, M. L., Bonan, G. B., Bretherton, C. S., Carton, J. A., Chang, P., Doney, S. C., Hack, J. J., Henderson, T. B., Kiehl, J. T., Large, W. G., McKenna, D. S., Santer, B. D., and Smith, R. D.: The Community Climate System Model version 3 (CCSM3), J. Climate, 19, 2122-2143, $2006 \mathrm{~b}$.

Cooper, W. A.: Ice initiation in natural clouds. precipitation enhancement - a scientific challenge, Meteor. Mon., 43, 29-32, 1986.

Corti, T., Luo, B. P., Peter, T., Vömel, H., and Fu, Q.: Mean radiative energy balance and vertical mass fluxes in the equatorial upper troposphere and lower stratosphere, Geophys. Res. Lett., 32, L06802, doi:10.1029/2004g1021889, 2005.

Cotton, W. R., Tripoli, G. J., Rauber, R. M., and Mulvihill, E. A.: Numerical simulations of effects of varying ice crystal nucleation rates and aggregation processes on orographic snowfall, J. Clim. App. Met, 25, 1659-1680, 1986.

Curry, J. A. and Khvorostyanov, V. I.: Assessment of some parameterizations of heterogeneous ice nucleation in cloud and climate 
models, Atmos. Chem. Phys., 12, 1151-1172, doi:10.5194/acp12-1151-2012, 2012.

Cziczo, D. J., Murphy, D. M., Hudson, P. K., and Thomson, D. S.: Single particle measurements of the chemical composition of cirrus ice residue during CRYSTAL-FACE, J. Geophys. Res., 109, D04201, doi:10.1029/2003jd004032, 2004.

DeMott, P. J., Meyers, M. P., and Cotton, W. R.: Parameterization and Impact of Ice Initiation Processes Relevant to NumericalModel Simulations of Cirrus Clouds, J. Atmos. Sci., 51, 15771577, 1994.

DeMott, P. J., Rogers, D. C., Kreidenweis, S. M., Chen, Y. L., Twohy, C. H., Baumgardner, D., Heymsfield, A. J., and Chan, K. R.: The role of heterogeneous freezing nucleation in upper tropospheric clouds: Inferences from SUCCESS, Geophys. Res. Lett., 25, 1387-1390, 1998.

DeMott, P. J., Rogers, D. C., Kreidenweis, S. M., and Chen, Y. L.: Laboratory studies of ice nucleation by aerosol particles in upper tropospheric conditions, Aip. Conf. Proc., 534, 451-454, 2000.

DeMott, P. J., Cziczo, D. J., Prenni, A. J., Murphy, D. M., Kreidenweis, S. M., Thomson, D. S., Borys, R., and Rogers, D. C.: Measurements of the concentration and composition of nuclei for cirrus formation, P. Natl. Acad. Sci. USA, 100, 14655-14660, doi:10.1073/pnas.2532677100, 2003.

DeMott, P. J., Prenni, A. J., Liu, X., Kreidenweis, S. M., Petters, M. D., Twohy, C. H., Richardson, M. S., Eidhammer, T., and Rogers, D. C.: Predicting global atmospheric ice nuclei distributions and their impacts on climate, P. Natl. Acad. Sci. USA, 107, 1121711222, doi:10.1073/pnas.0910818107, 2010.

Eidhammer, T., DeMott, P. J., and Kreidenweis, S. M.: A comparison of heterogeneous ice nucleation parameterizations using a parcel model framework, J. Geophys. Res., 114, D06202, doi:10.1029/2008JD011095, 2009.

Field, P. R., Wood, R., Brown, P. R. A., Kaye, P. H., Hirst, E., Greenaway, R., and Smith, J. A.: Ice particle interarrival times measured with a fast FSSP, J. Atmos. Ocean Tech., 20, 249-261, 2003.

Fletcher, N. H.: Physics of Rain Clouds, Cambridge Univ. Press, New York, 1962.

Froyd, K. D., Murphy, D. M., Sanford, T. J., Thomson, D. S., Wilson, J. C., Pfister, L., and Lait, L.: Aerosol composition of the tropical upper troposphere, Atmos. Chem. Phys., 9, 4363-4385, doi:10.5194/acp-9-4363-2009, 2009.

Gettelman, A., Randel, W. J., Wu, F., and Massie, S. T.: Transport of water vapor in the tropical tropopause layer, Geophys. Res. Lett., 29, 1009, doi:10.1029/2001g1013818, 2002.

Gettelman, A., Fetzer, E. J., Eldering, A., and Irion, F. W.: The Global Distribution of Supersaturation in the Upper Troposphere from the Atmospheric Infrared Sounder, J. Climate, 19, 60896103, doi:10.1175/jcli3955.1, 2006a.

Gettelman, A., Walden, V. P., Miloshevich, L. M., Roth, W. L., and Halter, B.: Relative humidity over Antarctica from radiosondes, satellites, and a general circulation model, J. Geophys. Res., 111, D09S13, doi:10.1029/2005jd006636, 2006b.

Gettelman, A., Morrison, H., and Ghan, S. J.: A new twomoment bulk stratiform cloud microphysics scheme in the community atmosphere model, version 3 (CAM3). Part II: Single-colunm and global results, J. Climate, 21, 3660-3679, doi:10.1175/2008jcli2116.1, 2008.
Gettelman, A., Liu, X., Ghan, S. J., Morrison, H., Park, S., Conley, A. J., Klein, S. A., Boyle, J., Mitchell, D. L., and Li, J. L. F.: Global simulations of ice nucleation and ice supersaturation with an improved cloud scheme in the Community Atmosphere Model, J. Geophys. Res., 115, D18216, doi:10.1029/2009jd013797, 2010.

Gierens, K., Schumann, U., Helten, M., Smit, H., and Marenco, A.: A distribution law for relative humidity in the upper troposphere and lower stratosphere derived from three years of MOZAIC measurements, Ann. Geophys., 17, 1218-1226, doi:10.1007/s00585-999-1218-7, 1999.

Haag, W., Kärcher, B., Ström, J., Minikin, A., Lohmann, U., Ovarlez, J., and Stohl, A.: Freezing thresholds and cirrus cloud formation mechanisms inferred from in situ measurements of relative humidity, Atmos. Chem. Phys., 3, 1791-1806, doi:10.5194/acp3-1791-2003, 2003.

Hendricks, J., Kärcher, B., and Lohmann, U.: Effects of ice nuclei on cirrus clouds in a global climate model, J. Geophys. Res., 116, D18206, doi:10.1029/2010JD015302, 2011.

Heymsfield, A. J.: On measurements of small ice particles in clouds, Geophys. Res. Lett., 34, L23812, doi:10.1029/2007g1030951, 2007.

Hoyle, C. R., Luo, B. P., and Peter, T.: The origin of high ice crystal number densities in cirrus clouds, J. Atmos. Sci., 62, 2568-2579, 2005.

Iacono, M. J., Delamere, J. S., Mlawer, E. J., Shephard, M. W., Clough, S. A., and Collins, W. D.: Radiative forcing by long-lived greenhouse gases: Calculations with the AER radiative transfer models, J. Geophys. Res., 113, D13103, doi:10.1029/2008jd009944, 2008.

Jensen, E. J., Lawson, P., Baker, B., Pilson, B., Mo, Q., Heymsfield, A. J., Bansemer, A., Bui, T. P., McGill, M., Hlavka, D., Heymsfield, G., Platnick, S., Arnold, G. T., and Tanelli, S.: On the importance of small ice crystals in tropical anvil cirrus, Atmos. Chem. Phys., 9, 5519-5537, doi:10.5194/acp-9-5519-2009, 2009.

Jensen, E. J., Pfister, L., Bui, T.-P., Lawson, P., and Baumgardner, D.: Ice nucleation and cloud microphysical properties in tropical tropopause layer cirrus, Atmos. Chem. Phys., 10, 1369-1384, doi:10.5194/acp-10-1369-2010, 2010.

Kärcher, B. and Burkhardt, U.: A cirrus cloud scheme for general circulation models, Q. J. Roy. Meteor. Soc., 134, 1439-1461, doi:10.1002/Qj.301, 2008.

Kärcher, B. and Lohmann, U.: A parameterization of cirrus cloud formation: Homogeneous freezing including effects of aerosol size, J. Geophys. Res.-Atmos., 107, 4698, doi:10.1029/2001jd001429, 2002a.

Kärcher, B. and Lohmann, U.: A parameterization of cirrus cloud formation: Homogeneous freezing of supercooled aerosols, J. Geophys. Res.-Atmos., 107, 4010, doi:10.1029/2001jd000470, 2002b.

Kärcher, B. and Lohmann, U.: A parameterization of cirrus cloud formation: Heterogeneous freezing, J. Geophys. Res., 108, 4402, doi:10.1029/2002jd003220, 2003.

Kärcher, B., Hendricks, J., and Lohmann, U.: Physically based parameterization of cirrus cloud formation for use in global atmospheric models, J. Geophys. Res., 111, D01205, doi:10.1029/2005JD006219, 2006. 
Kärcher, B., Möhler, O., DeMott, P. J., Pechtl, S., and Yu, F.: Insights into the role of soot aerosols in cirrus cloud formation, Atmos. Chem. Phys., 7, 4203-4227, doi:10.5194/acp-7-4203-2007, 2007.

Kay, J. E. and Gettelman, A.: Cloud influence on and response to seasonal Arctic sea ice loss, J. Geophys. Res., 114, D18204, doi:10.1029/2009jd011773, 2009.

Khvorostyanov, V. I. and Curry, J. A.: A new theory of heterogeneous nucleation for application in cloud and climate models, Geophys. Res. Lett., 27, 4081-4084, 2000.

Khvorostyanov, V. I. and Curry, J. A.: The theory of ice nucleation by heterogeneous freezing of deliquescent mixed CCN. part I: Critical radius, energy and nucleation rate, J. Atmos. Sci, 61, 2676-2691, 2004.

Koop, T., Luo, B. P., Tsias, A., and Peter, T.: Water activity as the determinant for homogeneous ice nucleation in aqueous solutions, Nature, 406, 611-614, 2000.

Korolev, A. and Isaac, G. A.: Relative humidity in liquid, mixedphase, and ice clouds, J. Atmos. Sci., 63, 2865-2880, 2006.

Krämer, M., Schiller, C., Afchine, A., Bauer, R., Gensch, I., Mangold, A., Schlicht, S., Spelten, N., Sitnikov, N., Borrmann, S., de Reus, M., and Spichtinger, P.: Ice supersaturations and cirrus cloud crystal numbers, Atmos. Chem. Phys., 9, 3505-3522, doi:10.5194/acp-9-3505-2009, 2009.

Lamarque, J.-F., Bond, T. C., Eyring, V., Granier, C., Heil, A., Klimont, Z., Lee, D., Liousse, C., Mieville, A., Owen, B., Schultz, M. G., Shindell, D., Smith, S. J., Stehfest, E., Van Aardenne, J., Cooper, O. R., Kainuma, M., Mahowald, N., McConnell, J. R., Naik, V., Riahi, K., and van Vuuren, D. P.: Historical (1850-2000) gridded anthropogenic and biomass burning emissions of reactive gases and aerosols: methodology and application, Atmos. Chem. Phys., 10, 7017-7039, doi:10.5194/acp10-7017-2010, 2010.

Lawson, R. P.: Effects of ice particles shattering on the 2D-S probe, Atmos. Meas. Tech., 4, 1361-1381, doi:10.5194/amt-4-13612011, 2011.

Lawson, R. P., O'Connor, D., Zmarzly, P., Weaver, K., Baker, B. A., Mo, Q., and Jonsson, H.: The 2D-S (Stereo) Probe: Design and preliminary tests of a new airborne, high speed, high-resolution particle imaging probe, J. Atmos. Ocean. Tech., 23, 1462-1477, 2006.

Liou, K. N.: Influence of Cirrus Clouds on Weather and Climate Processes - a Global Perspective, Mon. Weather Rev., 114, 1167-1199, 1986.

Liu, X., Penner, J. E., Ghan, S. J., and Wang, M.: Inclusion of ice microphysics in the NCAR community atmospheric model version 3 (CAM3), J. Climate, 20, 4526-4547, doi:10.1175/Jcli4264.1, 2007.

Liu, X., Easter, R. C., Ghan, S. J., Zaveri, R., Rasch, P., Shi, X., Lamarque, J.-F., Gettelman, A., Morrison, H., Vitt, F., Conley, A., Park, S., Neale, R., Hannay, C., Ekman, A. M. L., Hess, P., Mahowald, N., Collins, W., Iacono, M. J., Bretherton, C. S., Flanner, M. G., and Mitchell, D.: Toward a minimal representation of aerosols in climate models: description and evaluation in the Community Atmosphere Model CAM5, Geosci. Model Dev., 5, 709-739, doi:10.5194/gmd-5-709-2012, 2012.

Liu, X., Penner, J. E., and Wang, M.: Influence of anthropogenic sulfate and soot on upper tropospheric clouds using CAM3 coupled with an aerosol model, J. Geophys. Res., 114, D03204,
doi:10.1029/2008JD010492, 2009.

Liu, X. H. and Penner, J. E.: Ice nucleation parameterization for global models, Meteorol. Z., 14, 499-514, doi:10.1127/09412948/2005/0059, 2005.

Lohmann, U. and Roeckner, E.: Influence of Cirrus Cloud Radiative Forcing on Climate and Climate Sensitivity in a GeneralCirculation Model, J. Geophys. Res.-Atmos., 100, 16305-16323, 1995.

Lohmann, U., Spichtinger, P., Jess, S., Peter, T., and Smit, H.: Cirrus cloud formation and ice supersaturated regions in a global climate model, Environ. Res. Lett., 3, 045022, doi:10.1088/17489326/3/4/045022, 2008.

McFarquhar, G. M., Um, J., Freer, M., Baumgardner, D., Kok, G. L., and Mace, G.: Importance of small ice crystals to cirrus properties: Observations from the Tropical Warm Pool International Cloud Experiment (TWP-ICE), Geophys. Res. Lett., 34, L13803, doi:10.1029/2007g1029865, 2007.

Meyers, M. P., Demott, P. J., and Cotton, W. R.: New Primary Ice-Nucleation Parameterizations in an Explicit Cloud Model, J. Appl. Meteorol., 31, 708-721, 1992.

Morrison, H. and Gettelman, A.: A new two-moment bulk stratiform cloud microphysics scheme in the community atmosphere model, version 3 (CAM3). Part I: Description and numerical tests, J. Climate, 21, 3642-3659, doi:10.1175/2008jcli2105.1, 2008.

Murray, B. J., Wilson, T. W., Dobbie, S., Cui, Z., Al-Jumur, S. M. R. K., Möhler, O., Schnaiter, M., Wagner, R., Benz, S., Niemand, M., Saathoff, H., Ebert, V., Wagner, S., and Kärcher, B.: Heterogeneous nucleation of ice particles on glassy aerosols under cirrus conditions, Nat. Geosci., 3, 233-237, doi:10.1038/ngeo817, 2010.

Neale, R. B., Richter, J. H., and Jochum, M.: The Impact of Convection on ENSO: From a Delayed Oscillator to a Series of Events, J. Climate, 21, 5904-5924, doi:10.1175/2008jcli2244.1, 2008.

Neale, R. B., Chen, C.-C., Gettelman, A., Lauritzen, P. H., Park, S., Williamson, D. L., Conley, A. J., Garcia, R., Kinnison, D., Lamarque, J.-F., Marsh, D., Mills, M., Smith, A. K., Tilmes, S., Vitt, F., Cameron-Smith, P., Collins, W. D., Iacono, M. J., Easter, R. C., Ghan, S. J., Liu, X., Rasch, P. J., and Taylor, M. A.: Description of the NCAR Community Atmosphere Model (CAM 5.0), NCAR Technical Note, http://www.cesm.ucar.edu/models/ cesm1.0/cam/docs/description/cam5_desc.pdf, June 2010.

Park, S. and Bretherton, C. S.: The University of Washington Shallow Convection and Moist Turbulence Schemes and Their Impact on Climate Simulations with the Community Atmosphere Model, J. Climate, 22, 3449-3469, doi:10.1175/2008jcli2557.1, 2009.

Park, S., Bretherton, C. S., and Rasch, P. J.: Global cloud simulation in the Community Atmosphere Model, J. Climate, submitted, 2012.

Peter, T., Marcolli, C., Spichtinger, P., Corti, T., Baker, M. B., and Koop, T.: When dry air is too humid, Science, 314, 1399-1402, doi:10.1126/science.1135199, 2006.

Phillips, V. T. J., Donner, L. J., and Garner, S. T.: Nucleation processes in deep convection simulated by a cloud-system-resolving model with double-moment bulk microphysics, J. Atmos. Sci., 64, 738-761, doi:10.1175/Jas3869.1, 2007.

Phillips, V. T. J., DeMott, P. J., and Andronache, C.: An empirical parameterization of heterogeneous ice nucleation for multiple 
chemical species of aerosol, J. Atmos. Sci., 65, 2757-2783, doi:10.1175/2007jas2546.1, 2008.

Pruppacher, H. R. and Klett, J. D.: Microphysics of Cloud and Precipitation, Springer, New York, 954 pp., 1997.

Ramanathan, V. and Collins, W.: Thermodynamic Regulation of Ocean Warming by Cirrus Clouds Deduced from Observations of the 1987 El-Nino, Nature, 351, 27-32, 1991.

Rosenfield, J. E., Considine, D. B., Schoeberl, M. R., and Browell, E. V.: The impact of subvisible cirrus clouds near the tropical tropopause on stratospheric water vapor, Geophys. Res. Lett., 25, 1883-1886, doi:10.1029/98GL01294, 1998.

Slingo, J. M.: The Development and Verification of a Cloud Prediction Scheme for the Ecmwf Model, Q. J. Roy. Meteor. Soc., 113, 899-927, 1987.

Spichtinger, P. and Gierens, K. M.: Modelling of cirrus clouds - Part 1b: Structuring cirrus clouds by dynamics, Atmos. Chem. Phys., 9, 707-719, doi:10.5194/acp-9-707-2009, 2009a.

Spichtinger, P. and Gierens, K. M.: Modelling of cirrus clouds - Part 2: Competition of different nucleation mechanisms, Atmos. Chem. Phys., 9, 2319-2334, doi:10.5194/acp-9-2319-2009, 2009b.

Szyrmer, W. and Zawadzki, I.: Biogenic and anthropogenic sources of ice-forming nuclei: A review, B. Am. Meteorol. Soc., 78, 209228, 1997.
Wang, M. and Penner, J. E.: Cirrus clouds in a global climate model with a statistical cirrus cloud scheme, Atmos. Chem. Phys., 10, 5449-5474, doi:10.5194/acp-10-5449-2010, 2010.

Wang, P.-H., Minnis, P., McCormick, M. P., Kent, G. S., Yue, G. K., Young, D. F., and Skeens, K. M.: A 6-year climatology of cloud occurence frequency from Stratospheric Aerosol and Gas experiment II observations (1985-1990), J. Geophys. Res, 101, 29407-29429, 1996.

Wielicki, B. A., Barkstrom, B. R., Harrison, E. F., Lee, R. B., Smith, G. L., and Cooper, J. E.: Clouds and the Earth's Radiant Energy System (CERES): An earth observing system experiment, B. Am. Meteorol. Soc., 77, 853-868, 1996.

Wylie, D. P. and Menzel, W. P.: Eight years of high cloud statistics using HIRS, J. Climate, 12, 170-184, 1999.

Young, K. C.: The role of contact nucleation in ice phase initiation in clouds, J. Atmos. Sci, 31, 768-776, 1974.

Zender, C., Bian, H., and Newman, D.: Mineral Dust Entrainment and Deposition (DEAD) model: Description and 1990s dust climatology, J. Geophys. Res., 108, 4416, doi:4410.1029/2002JD002775, 2003.

Zhang, K., Liu, X., Comstock, J. M., Wang, M., Wan, H., and Bui, T. V.: Characteristics of vertical velocity in cirrus clouds and its impact on ice nucleation: evaluation and Inter-comparison of two global climate models, in preparation, 2012. 